\title{
LEVERAGING THE TRINITY: A 'CLAUSEWITZIAN' FRAMEWORK FOR GENOCIDE PREVENTION
}

\author{
A Monograph \\ by \\ Mr. Anthony L. Volino \\ Department of the Army Civilian
}

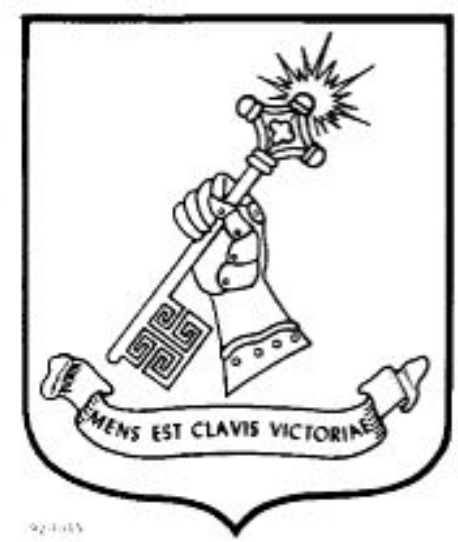

School of Advanced Military Studies

United States Army Command and General Staff College

Fort Leavenworth, Kansas

AY 2014-01 


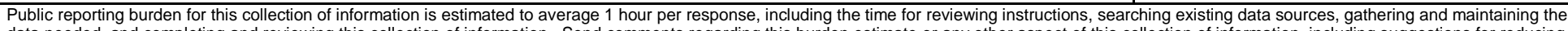

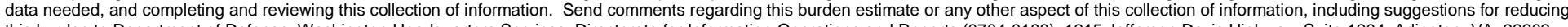

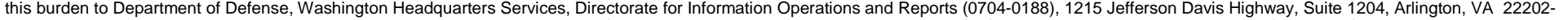

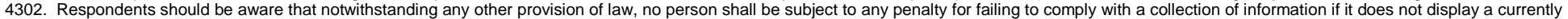
valid OMB control number. PLEASE DO NOT RETURN YOUR FORM TO THE ABOVE ADDRESS.

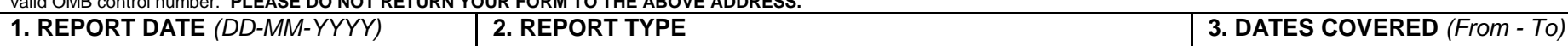

15-05-2014

SAMS Monograph

JUNE 2013 - MAY 2014

4. TITLE AND SUBTITLE

5a. CONTRACT NUMBER

Leveraging the Trinity: A ‘Clausewitzian’ Framework for Genocide Prevention

5b. GRANT NUMBER

5c. PROGRAM ELEMENT NUMBER

6. AUTHOR(S)

5d. PROJECT NUMBER

Mr. Anthony L. Volino, U.S. Army North

5e. TASK NUMBER

5f. WORK UNIT NUMBER

8. PERFORMING ORGANIZATION REPORT

U.S. Army School of Advanced Military Studies

ATTN: ATZL-SWD-GD

1 Reynolds Ave.

Fort Leavenworth, KS 66027-2301

9. SPONSORING / MONITORING AGENCY NAME(S) AND ADDRESS(ES)

10. SPONSOR/MONITOR'S ACRONYM(S)

11. SPONSOR/MONITOR'S REPORT NUMBER(S)

\section{DISTRIBUTION / AVAILABILITY STATEMENT}

Approved for Public Release; Distribution is Unlimited

\section{SUPPLEMENTARY NOTES}

\section{ABSTRACT}

The twenty-first century has seen an increased interest in genocide response by the US military. Despite the development of these new approaches to dealing with the problem of genocide, gaps remain. Little research has been done on the role of the military in genocide prevention. Further complicating the development of military approaches to genocide prevention is the fact that the research on the causes and indicators of genocide is distributed across several different academic disciplines. This research examines the indicators and causes of genocide from the Clausewitzian perspective that genocide, like war and other forms of collective violence, is an extension of politics. It proposes extending the concept of Clausewitz's paradoxical trinity to the phenomenon of genocide and its corresponding roles of the genocidal population, genocide perpetrators, and genocide leaders in order to synthesize the existing body of research on genocide. Finally, the paper links the causes of genocide to military prevention capabilities, thereby proposing a framework for genocide and mass atrocity prevention in Phases 0 and 1. The work concludes with the risks and opportunities inherent in such a strategy.

\section{SUBJECT TERMS}

Genocide Prevention, Mass Atrocity Response Operations, R2P

16. SECURITY CLASSIFICATION OF:

\begin{tabular}{c|c|c|} 
a. REPORT & b. ABSTRACT & c. THIS PAGE \\
$\mathrm{U}$ & $\mathrm{U}$ & $\mathrm{U}$ \\
\hline
\end{tabular}

17. LIMITATION OF ABSTRACT

UU
18. NUMBER OF PAGES

69 19a. NAME OF RESPONSIBLE PERSON

Mr. Anthony L Volino

19b. TELEPHONE NUMBER (include area code) 


\section{MONOGRAPH APPROVAL}

Name of Candidate: Anthony L. Volino

Monograph Title: $\quad$ Leveraging the Trinity: A ‘Clausewitzian’ Framework for Genocide Prevention

Approved by:

Alice A. Butler-Smith, Ph.D.

, Monograph Director

Jerry A. Turner, COL

, Seminar Leader

Henry A. Arnold III, COL, IN

, Director, School of Advanced Military Studies

Accepted this 22nd day of May 2014 by:

Robert F. Baumann, Ph.D.

, Director, Graduate Degree Programs

The opinions and conclusions expressed herein are those of the student author, and do not necessarily represent the views of the U.S. Army Command and General Staff College or any other government agency. (References to this study should include the foregoing statement.) 


\begin{abstract}
LEVERAGING THE TRINITY: A ‘CLAUSEWITZIAN’ FRAMEWORK FOR GENOCIDE PREVENTION, by Mr. Anthony L. Volino, Department of the Army Civilian, 69 pages.

The twenty-first century has seen an increased interest in genocide response by the US military. Despite the development of these new approaches to dealing with the problem of genocide, gaps remain. Little research has been done on the role of the military in genocide prevention. Further complicating the development of military approaches to genocide prevention is the fact that the research on the causes and indicators of genocide is distributed across several different academic disciplines. This research examines the indicators and causes of genocide from the Clausewitzian perspective that genocide, like war and other forms of collective violence, is an extension of politics. It proposes extending the concept of Clausewitz's paradoxical trinity to the phenomenon of genocide and its corresponding roles of the genocidal population, genocide perpetrators, and genocide leaders in order to synthesize the existing body of research on genocide. Finally, the paper links the causes of genocide to military prevention capabilities, thereby proposing a framework for genocide and mass atrocity prevention in Phases 0 and 1 . The work concludes with the risks and opportunities inherent in such a strategy.
\end{abstract}




\section{ACKNOWLEDGEMENTS}

I am truly honored by the opportunity extended to me by the US Army and the School of Advanced Military Studies (SAMS) to participate in this outstanding program. The many hours put into the course and this monograph have placed me in the debt of many people. To them I offer my sincere thanks and gratitude for their support throughout this process. First, to my sisterin-law, Kristi, for her countless hours spent providing spelling, grammar, and logic checks. To Mr. Johnny Lairsey for providing support and guidance in the application process. To my coworkers and supervisors at US Army North, Mr. Roger Bass foremost among them, for picking up the slack in my absence. And finally, to my wife, Rebecca, for her understanding and strength throughout this past year. You have been my source of energy throughout this course and a blessing in my life. 


\section{TABLE OF CONTENTS}

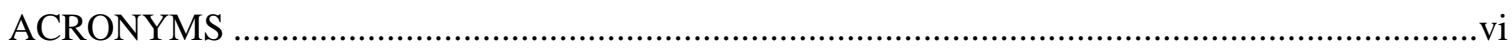

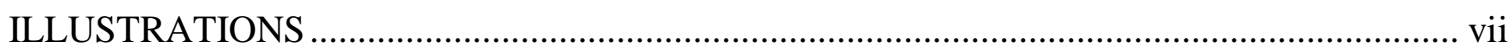

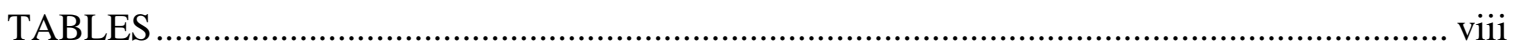

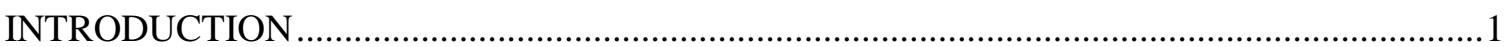

Current Approaches to Genocide Prevention and Response: Insufficient but Evolving ............ 4

A Clausewitzian Problem: Genocide, Politics, and the Paradoxical Trinity.............................. 8

REVIEW OF GENOCIDE CAUSES AND INDICATORS .......................................................14

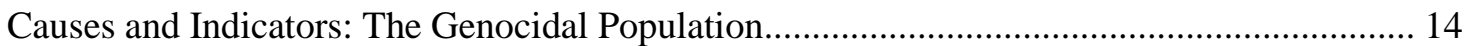

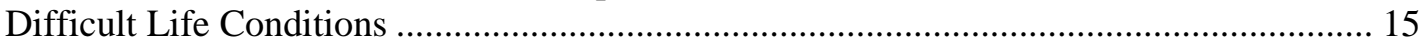

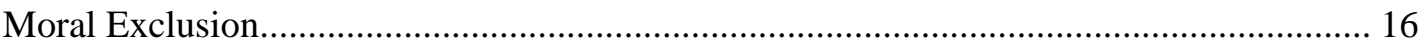

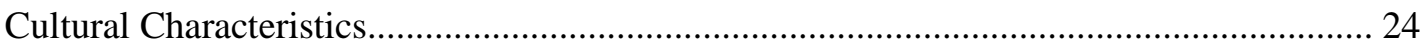

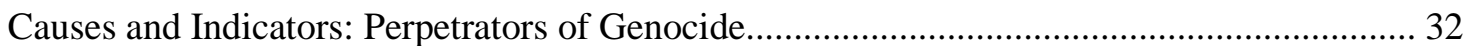

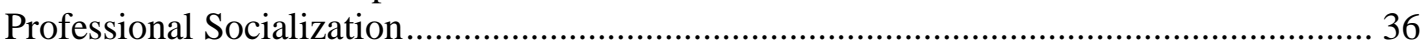

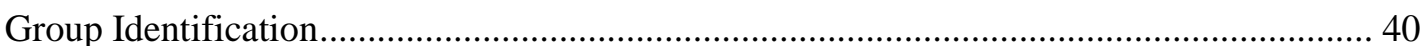

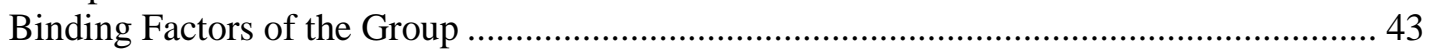

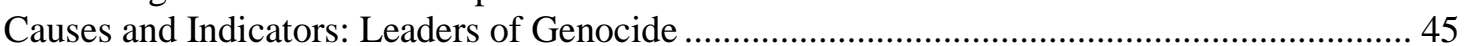

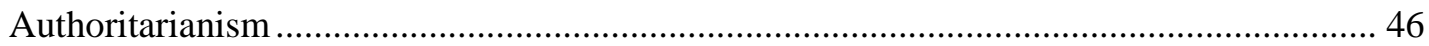

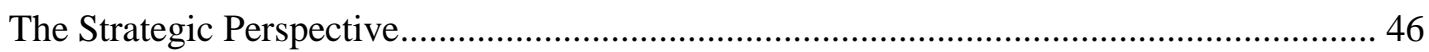

LEVERAGING THE TRINITY: GENOCIDE PREVENTION ..................................................50

Genocide Prevention Efforts Targeting the Genocidal Population ............................................ 51

Genocide Prevention Efforts Targeting Potential Perpetrators of Genocide ........................... 55

Genocide Prevention Efforts Targeting Leaders of Genocide ................................................ 58

CONCLUSION: RISK AND OPPORTUNITY FOR THE MILITARY IN GENOCIDE

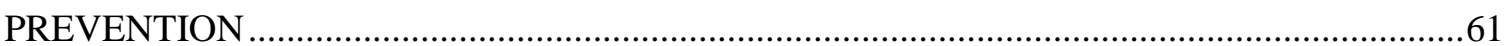

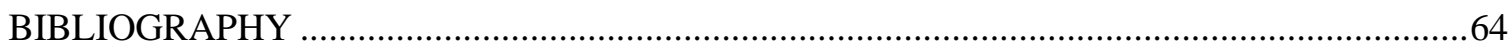




\section{ACRONYMS}

$\begin{array}{ll}\text { APB } & \text { Atrocities Prevention Board } \\ \text { DIME } & \text { Diplomatic, Informational, Military, and Economic } \\ \text { DoD } & \text { Department of Defense } \\ \text { FDO } & \text { Flexible Deterrent Options } \\ \text { GPTF } & \text { Genocide Prevention Task Force } \\ \text { ICISS } & \text { International Commission on Intervention and State Sovereignty } \\ \text { JOPP } & \text { Joint Operations Planning Process } \\ \text { MAPRO } & \text { Mass Atrocity Prevention and Response Options } \\ \text { MARO } & \text { Mass Atrocity Response Operation } \\ \text { MISO } & \text { Military Information Support Operations } \\ \text { PKSOI } & \text { Peacekeeping and Stability Operations Institute } \\ \text { PSD-10 } & \text { Presidential Study Directive-10 } \\ \text { R2P } & \text { Responsibility to Protect } \\ \text { RAF } & \text { Regionally Aligned Forces } \\ \text { SC } & \text { Security Cooperation } \\ \text { UN } & \text { United Nations } \\ \text { USG } & \text { United States Government }\end{array}$




\section{ILLUSTRATIONS}

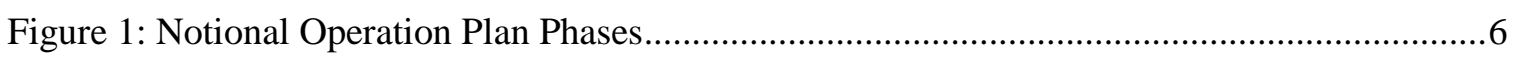

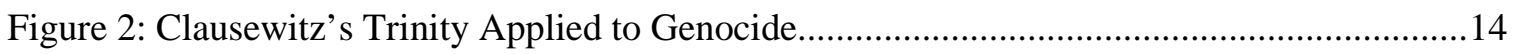

Figure 3: James Waller’s Model of How Ordinary People Commit Genocide and

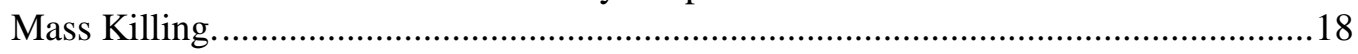

Figure 4: Causes and Indicators of Genocide Expressed Through the Trinity..............................50

Figure 5: ‘Trinitarian’ Framework for Genocide Prevention. .................................................60 


\section{TABLES}

Table 1: Goldhagen's Patterns of Dehumanization and Demonization of Eliminationist

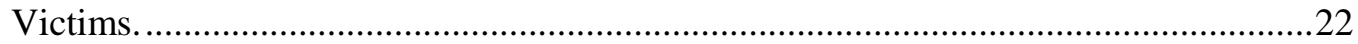

Table 2: Valentino’s Intent-Based Typology of Mass Killing. …...............................................47 


\section{INTRODUCTION}

Bad men need nothing more to compass their ends, than that good men should look on and do nothing.

—John Stuart Mill, Inaugural Address at St. Andrews

Genocide is a problem that has plagued humankind for millennia. The landscape of human history is marred with countless tales of genocide and other forms of one-sided, mass killings. Thucydides told the story of the Athenian conquest of the island of Melos, after which the victors executed the island's men, and sold the women and children into slavery. ${ }^{1}$ Cato the Elder's famous incitement to genocide - Delenda est Carthago - or "Carthage must be destroyed!" was answered by the Roman destruction of Carthage and its surrounding settlements in the aftermath of the Punic Wars. ${ }^{2}$ The Mongols and Assyrians were expert practitioners of genocide, and are thought to have removed entire populations from the historical record. ${ }^{3}$

Numerous other examples can be drawn from across the centuries and civilizations; however, the "odious scourge" of genocide reached its zenith in the twentieth century. ${ }^{4}$ From the machine-like efficiency of the Holocaust to the agrarian brutality of the Rwandan genocide, the twentieth century witnessed the deaths of approximately 169 million victims, over four times the amount of deaths resulting from wars during the same time period. ${ }^{5}$

${ }^{1}$ Thucydides, The History of the Peloponnesian War, ed. and trans. Richard Crawley (Digireads.com, 2009), v.

${ }^{2}$ Plutarch, Plutarch’s Moralia, ed. and trans. Frank Cole Babbitt (London: Heinemann, 1992), 27. Polybius, The Histories Vol. 6, ed. and trans.William Roger Paton (Cambridge, MA [U.A.]: Harvard Univ. Press, 2000), xxxviii. Appian, Appian's Roman History in Four Volumes, ed. and trans. Horace White, [Tome]1 (London; Cambridge: W. Heinemann ; Harvard University Press, 1972), 19.

${ }^{3}$ Frank Robert Chalk and Kurt Jonassohn, The History and Sociology of Genocide: Analyses and Case Studies (New Haven: Yale University Press, 1990), 33.

${ }^{4}$ This reference to genocide as an odious scourge is borrowed from the preamble to the Convention on Genocide. United Nations, General Assembly Resolution 260A(III) of 9 December 1948.

${ }^{5}$ R. J. Rummel, Death by Government (New Brunswick, NJ: Transactions Publishers, 1994), 1-3. 
In contrast to the brutality of the twentieth century, this century has seen an increased interest in solving the problem of genocide. Samantha Power’s book, “A Problem from Hell”: America and the Age of Genocide, shed light on genocide and how the international community can better support prevention and response efforts. ${ }^{6}$ The United Nations (UN) supported the development of new norms in international relations intended to ensure that governments protect their citizens. The Obama administration has shown its dedication to genocide prevention by establishing an Atrocity Prevention Board (APB) to develop prevention and response policy. The US military has also begun to flesh out its role in genocide prevention and response by working with the Harvard Carr Center to produce two handbooks: Mass Atrocity Response Operations (MARO): A Military Planning Handbook and Mass Atrocity Prevention \& Response Options (MAPRO): A Policy Planning Handbook, both of which are examined in this monograph.

While the military's efforts thus far represent progress towards the development of genocide response doctrine, there is currently a dearth of information available for military planners responsible for developing approaches to mass atrocity and genocide prevention. Further complicating the development of military approaches to genocide prevention is the fact that the research on the causes and indicators of genocide is distributed across several different academic disciplines, such as psychology, sociology, political science, and history. There is also relatively little research on genocide from the perspective of a military practitioner. The intent of this monograph is to solve these problems.

This monograph examines the indicators and causes of genocide from the Clausewitzian perspective that genocide, like war and other forms of collective violence, is an extension of politics. Clausewitz described war as a paradoxical trinity composed of passion, chance, and

${ }^{6}$ Power described the lack of will of governments to intervene as the central challenge to genocide prevention. Samantha Power, “A Problem from Hell”: America and the Age of Genocide (New York: Harper Perennial, 2007), 508-516. 
reason, which are primarily the concerns of the people, the army, and the government. ${ }^{7}$ Since this is a concept with which military planners should be familiar, this paper extends the concept of the trinity to the phenomenon of genocide and its corresponding roles of the genocidal population, genocide perpetrators, and genocide leaders. This monograph synthesizes the existing body of research on genocide through the concept of the trinity by examining the passions that inflame the genocidal population, the chance at play when encouraging potential perpetrators to conduct mass killings, and the reasoning at work when leaders implement a strategy of genocide. The monograph then matches the causes of genocide to military prevention capabilities, thereby proposing a framework for genocide and mass atrocity prevention that planners can use to guide actions in Phases 0 and 1, the period when genocide indicators are present but large-scale violence has not commenced, with the goal of obviating the need for a full-scale MARO.

To accomplish this goal, this monograph is arranged in the following manner. The first section examines the background information on genocide prevention efforts and why existing approaches are insufficient. The second section examines the definition of genocide and its relation to the Clausewitzian definition of war as "a continuation of political intercourse, carried on with other means.” ${ }^{\prime 8}$ After establishing the link between genocide and the Clausewitzian definition of war, the third section extends the concept of Clausewitz's paradoxical trinity to genocide in order to explore the disparate literature on genocide research as it relates to the trinitarian structures of the genocidal population, the genocide perpetrators, and the genocide leaders. This section shows that the factors contributing to genocide follow the same logic of passion, chance, and reason that Clausewitz observed in war. The fourth section matches the causes of genocide with the military capabilities that are best suited to counter them, which fall 101.

${ }^{7}$ Carl von Clausewitz, On War, ed. Michael Howard and Peter Paret (New York: Knopf, 1993),

$$
{ }^{8} \text { Ibid., } 99 .
$$


under the general themes of information and development, military engagement, and deterrence. The monograph then concludes with the risks and opportunities inherent in such a strategy.

\section{Current Approaches to Genocide Prevention and Response: Insufficient but Evolving}

At the 2005 World Summit, the United States, and other Member States of the UN collectively agreed that each state has the responsibility to protect its population from genocide, war crimes, ethnic cleansing, and crimes against humanity. ${ }^{9}$ This emergent norm in international relations, known as the Responsibility to Protect (R2P), was derived from a paper of the same name published in 2001 by the International Commission on Intervention and State Sovereignty (ICISS). R2P challenged the prevailing Westphalian system of national sovereignty by proposing that the international system has a responsibility to intervene when nations fail to stop mass atrocities from occurring within their borders. To meet this expectation, R2P embraced three foundational responsibilities of the international system: the responsibility to prevent; the responsibility to react; and the responsibility to rebuild. ${ }^{10}$

R2P was reaffirmed by the UN Security Council in 2006 and in 2009 UN SecretaryGeneral Ban Ki-moon released a report on the implementation of R2P. The United States asserted its commitment to R2P, specifically its prevention and reaction components, in the 2010 National Security Strategy by stating that it would "work multilaterally and bilaterally to mobilize diplomatic, humanitarian, financial, and—in certain instances—-military means to prevent and respond to genocide and mass atrocities." ${ }^{11}$ Accordingly, the Department of Defense (DoD) declared in the 2012 National Defense Strategic Guidance that it would continue to develop

${ }^{9}$ United Nations Department of Public Information, 2005 World Summit Outcome Document Fact Sheet (September, 2005), 1.

${ }^{10}$ International Commission on Intervention and State Sovereignty, The Responsibility to Protect, (Ottawa: International Development Research Centre , 2001), XI.

${ }^{11}$ The White House, National Security Strategy (1 May 2010), 48. 
doctrine and response options to prevent and respond to mass atrocities. ${ }^{12}$ In August 2011, the White House released the Presidential Study Directive on Mass Atrocities (PSD-10) that established an interagency APB to develop atrocity prevention and response policy utilizing a full range of options. Key to the implementation of the APB was the analysis of existing tools and authorities for the prevention of atrocities along with the development of new tools. ${ }^{13}$

Recognizing a need for atrocity prevention and response understanding within the military, Sara Sewell of the Carr Center for Human Rights at the Harvard Kennedy School launched the MARO Project as a collaborative effort with the Army Peacekeeping and Stability Operations Institute (PKSOI) and the US Army War College. The MARO Project's goals were "to develop a widely shared understanding of the specific and unique aspects of mass atrocities and genocide and to create a common military approach . . . to address those challenges." ${ }^{14}$ The outcome of the MARO Project was the 2010 publication of the MARO Handbook.

The MARO Handbook’s primary audience is the commander and staff of a potential MARO Task Force to support the planning and execution of mass atrocity and genocide response operations. The handbook is aligned with the Joint Operations Planning Process (JOPP) and is divided into three parts: the first explains the specific characteristics of a MARO, the second addresses military planning considerations, and the third looks to future work on MARO by the military. The section on military planning considerations also contains potential courses of action that can be taken in the event of a MARO, which are divided into Flexible Deterrent Options (FDO) and operational approaches. FDOs are Diplomatic, Informational, Military, and Economic (DIME) actions that can be taken prior to an operation in order to dissuade an enemy from taking

\footnotetext{
${ }^{12}$ DoD, Sustaining US Global Leadership: Priorities for 21st Century Defense (January 2012),6.

${ }^{13}$ The White House, Presidential Study Directive-10 (4 August 2010).

${ }^{14}$ Sarah Sewell, Dwight Raymond, and Sally Chin, Mass Atrocity Response Operations: A Military Planning Handbook (Cambridge: Harvard University Press, 2010), 9.
} 
an undesired action or compel an enemy to take a desired action. ${ }^{15}$ FDOs are typically executed in Phase 0 (Shape) and Phase 1 (Deter) of an operation as depicted in a generic operational phasing construct (see fig. 1). If deterrence fails, direct military intervention may occur. The MARO Handbook proposes seven operational approaches that a task force may use when executing a MARO. These operational approaches make up the main thrust of the document; the MARO Handbook is primarily a guide for action. ${ }^{16}$

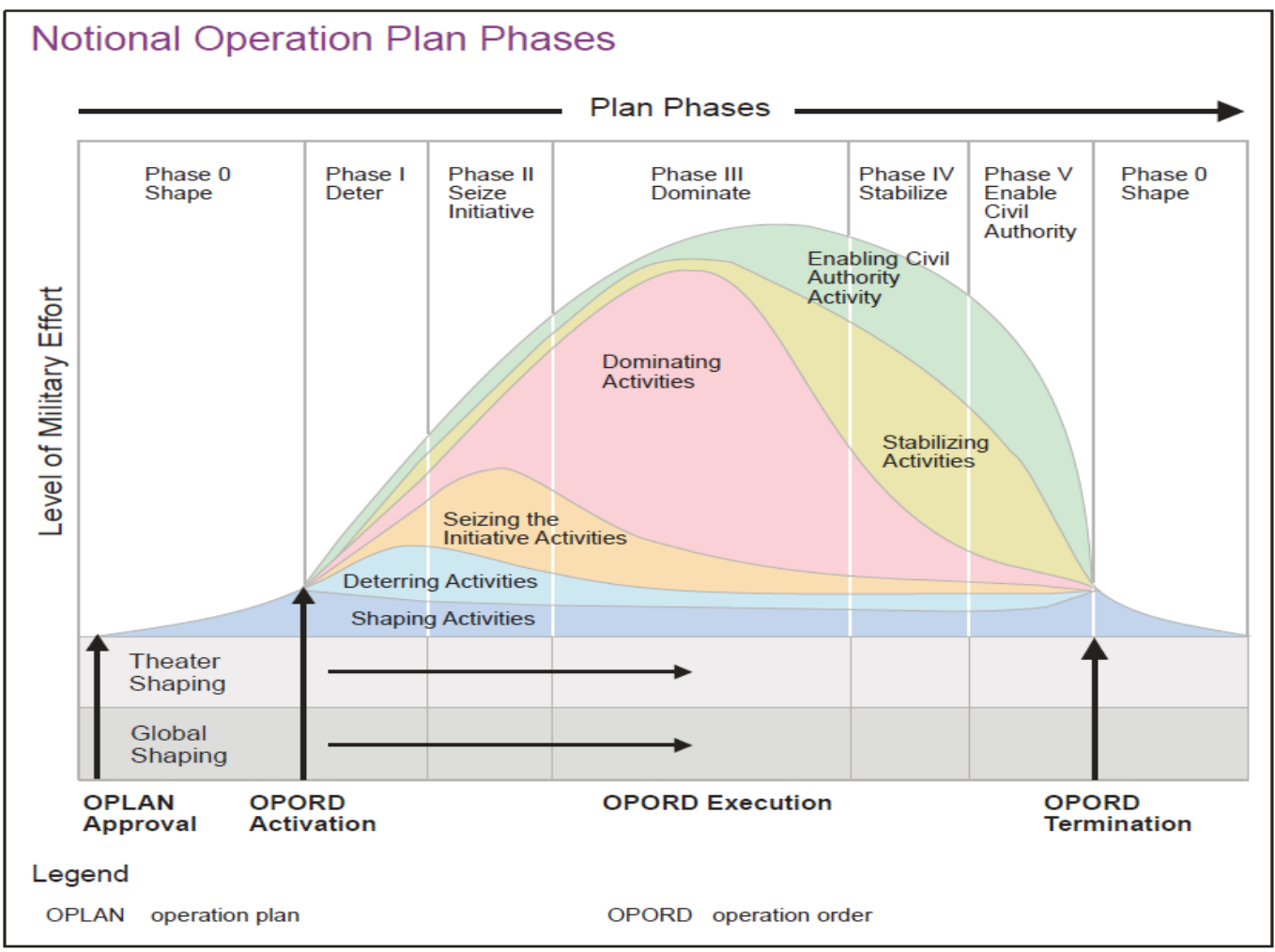

Figure 1: Notional Operation Plan Phases

Source: US Department of Defense, JP 5-0, Joint Operation Planning (Washington, DC: Government Printing Office, 2011), III-39.

${ }^{15}$ This definition differs slightly from that provided in JP 5-0 by the inclusion of suasion activities typically included in security cooperation activities. Sewell, Raymond, and Chin, MARO Handbook, 62.

${ }^{16}$ Ibid., 60. 
As with most military doctrine, the MARO Handbook generated ample analysis and feedback following its publication. Genocide Studies and Prevention dedicated its Spring 2011 issue to a critique of the handbook. The handbook's orientation towards military action, along with its underlying philosophical roots, were criticized as privileging military solutions over other options. ${ }^{17}$ Genocide scholar Uğur Üngör emphasized the handbook’s “inability to integrate the political dimension of genocide.” ${ }^{18}$ Alan Kuperman also noted the neglect of the political dimension and criticized the document's tendency to rely on simplistic scenarios. He indicted the handbook’s overall lack of strategy and instead recommended a "multi-pronged" approach that leverages all elements of national power. ${ }^{19}$ Common criticisms leveled at the handbook and its military audience were that the US military’s conduct during previous operations has been problematic, and that the military is not properly trained at the individual level for such operations. While some of these criticisms are common to most military operations, they illustrate the need for military approaches to genocide prevention that are holistic in nature and informed by theory.

In March 2012, the Army PKSOI with members of the Department of State and the MARO Project published MAPRO: A Policy Planning Handbook. This handbook was designed as a reference for interagency policy makers and senior leaders developing or deliberating on whole-of-government approaches to mass atrocity or genocide prevention and response. It provided a full menu of DIME actions that the government could take along three general MAPRO approaches: suasion, compellence, and intervention. Suasion was described as a primarily diplomatic approach that uses inducements and pressure to convince would-be

\footnotetext{
${ }^{17}$ Henry Theriault, “The MARO Handbook: New Possibilities or the Same Old Militarism?” Genocide Studies and Prevention 6, no. 1 (April 2011): 26.

${ }^{18}$ Ümit Üngör Uğur, “Team America: Genocide Prevention?” Genocide Studies and Prevention 6, no. 1 (April 2011): 32-38.

${ }^{19}$ Alan Kuperman, "Mass Atrocity Response Operations: Doctrine in Search of a Strategy" Genocide Studies and Prevention 6, no. 1 (April 2011): 60-63.
} 
perpetrators and their supporters to act responsibly." ${ }^{20}$ Compellence was defined as the "tools to punish, isolate, undermine, intimidate, or apply significant pressure to coerce perpetrators.”21 Lastly, intervention was described as the use of primarily military resources to stop mass atrocities.

The MARO Handbook provides an informational resource for the tactical headquarters tasked with responding to a mass atrocity. The MAPRO Handbook provides information and options to interagency policy makers. However, neither resource provides information for military planners responsible for developing approaches to mass atrocity and genocide prevention. Even more challenging for planners is the fact that the body of research on the causes and indicators of genocide is distributed across several different academic disciplines, and there is relatively little research on genocide from the perspective of a military practitioner. The following section takes this practitioner's view of genocide, and examines the link between genocide and the Clausewitzian perspective of war as an extension of politics. By establishing the link between genocide and the Clausewitzian conception of war, it allows for other ideas, in this case Clausewitz's paradoxical trinity, to be applied to understand the problem of genocide.

\section{A Clausewitzian Problem: Genocide, Politics, and the Paradoxical Trinity}

This section examines the link between genocide and the Clausewitzian concept of war as an extension of politics. This link forms the foundation and organizing logic of the remainder of the research by establishing that genocide is a Clausewitzian phenomenon that manifests with the same dominant trinitarian tendencies that make up war. In order to understand this relationship, it

\footnotetext{
${ }^{20}$ Dwight Raymond, Cliff Bernath, Don Braum, and Ken Zurcher, Mass Atrocity Prevention \& Response Options: A Policy Planning Handbook (Carlisle, PA: US Army Peacekeeping and Stability Operations Institute, 2012), 69.

${ }^{21}$ Ibid., 70.
} 
is important to first describe the usage of the term genocide and how it relates to war and other forms of one-sided violence.

Lawyer and activist Raphael Lemkin coined the term "genocide” in his work, Axis Rule in Occupied Europe, by combining the ancient Greek word genos (race, tribe) and the Latin word cide (killing). He defined this term as “the destruction of a nation or an ethnic group.” He explained that genocide did not mean the immediate destruction of a nation, but the systematic destruction of the foundation of a group’s existence. In his own words:

The objectives of such a plan would be the disintegration of the political and social institutions, of culture, language, national feelings, religion, and the economic existence of national groups, and the destruction of the personal security, liberty, health, dignity, and even the lives of the individuals belonging to such groups. Genocide is directed against the national group as an entity, and the actions involved are directed against individuals, not in their individual capacity, but as members of the national group.

Lemkin also discussed the techniques of genocide used by the Nazis in Europe, and he included eight fields in which the techniques were being carried out: political, social, cultural, economic, biological, physical, religious, and moral. ${ }^{22}$

In 1948, owing in large part to Lemkin’s lobbying, the UN General Assembly adopted the Convention on the Prevention and Punishment of the Crime of Genocide. Article 2 of the Convention defined genocide as:

... any of the following acts committed with the intent to destroy, in whole or in part, a national, ethnical, racial, or religious group, as such:

(a) Killing members of the group;

(b) Causing serious bodily or mental harm to members of the group;

(c) Deliberately inflicting on the group conditions of life calculated to bring about its physical destruction in whole or in part;

(d) Imposing measures intended to prevent births within the group;

(e) Forcibly transferring children of the group to another group. ${ }^{23}$ 82-90.

${ }^{22}$ Raphael Lemkin, Axis Rule in Occupied Europe (Clark, NJ: The Lawbook Exchange, 2005), 79,

${ }^{23}$ United Nations, General Assembly Resolution 260A(III) of 9 December 1948. 
The MARO Handbook avoids definitional problems by describing a MARO as "a contingency operation to halt the widespread and systematic use of violence by state or non-state armed groups against noncombatants.”24 This definition borrows from former Secretary of State Madeleine Albright's Genocide Prevention Task Force (GPTF) definition of genocide and mass atrocities as "large-scale and deliberate attacks on civilians.” 25 The GPTF goes further to avoid confusion by using the term genocide to refer to the wider group of crimes that merit international concern, including genocide, crimes against humanity, and war crimes. ${ }^{26}$ While these terms are not defined in the body of the MARO Handbook, the legal documents defining these terms are included in an annex to the handbook. The MAPRO Handbook, on the other hand, retains the definition of genocide established in the Genocide Convention and defines mass atrocities separately as “widespread and often systematic acts of violence against civilians or other noncombatants including killing; causing serious bodily or mental harm; or deliberately inflicting conditions of life that cause serious bodily or mental harm." ${ }^{27}$

Adding to the definitional confusion, genocide scholars often struggle to define exactly which actions constitute genocide. In his book, Genocide: Its Political Use in the Twentieth Century, sociologist Leo Kuper described the challenges the various UN committees faced while developing the definition of genocide for inclusion in the Genocide Convention. ${ }^{28}$ There were five main contentious issues: which groups should be protected; which actions should be characterized as genocide; the issue of intent; the question of how to quantify genocide; and the

${ }^{24}$ Sewell, Raymond, and Chin, MARO Handbook, 23.

${ }^{25}$ Genocide Prevention Task Force, Madeleine Korbel Albright, William S. Cohen, and John C. Danforth, Preventing Genocide: A Blueprint for US Policymakers (Washington, DC: American Academy of Diplomacy, 2008), xxii.

${ }^{26}$ Ibid.

${ }^{27}$ Raymond, Bernath, Braum, and Zurcher, MAPRO Handbook, 10.

${ }^{28}$ Leo Kuper, Genocide : Its Political Use in the Twentieth Century (New Haven: Yale University Press, 1982), 24-39. 
problem of enforcement. ${ }^{29}$ The final definition notably excluded political groups and certain acts of cultural genocide. Kuper retained the genocide convention definition in his work, but also made room for other genocidal acts in a chapter he titled, "Related Atrocities.”30

Other scholars have proposed revised definitions or alternative terms for genocide. Frank Chalk and Kurt Jonassohn broadened the definition of genocide to include any form of one-sided mass killing by a state or other authority with the goal of destroying a group. ${ }^{31}$ Political scientist R. J. Rummel introduced the term democide to mean "the murder of any person or people by a government, including genocide, politicide, and mass murder.” ${ }^{32}$ Sociologist Helen Fein offered a sociological definition of genocide as a "sustained purposeful action by a perpetrator to physically destroy a collectivity directly or indirectly, through interdiction of the biological and social reproduction of group members, sustained regardless of surrender or lack of threat offered by the victim.”33 Sociologist Martin Shaw, linking genocide to war, defined genocide and genocidal action as

... a form of violent social conflict or war, between armed power organizations that aim to destroy civilian social groups and those groups and other actors who resist this destruction. Genocidal action is action in which armed power organizations treat civilian social groups as enemies and aim to destroy their real or putative social power, by means of killing, violence and coercion against individuals whom they regard as members of the groups. ${ }^{34}$

These definitions illustrate the complexity of genocide and the difficulty in determining which violent actions should be included or excluded its definition.

\footnotetext{
${ }^{29}$ Alexander Laban Hinton, Genocide: An Anthropological Reader (Oxford, UK: Blackwell, 2002), 4.

${ }^{30}$ Kuper, Genocide, 39.

${ }^{31}$ Chalk and Jonassohn, 23.

${ }^{32}$ Rummel, 33.

${ }^{33}$ Helen Fein, Genocide: A Sociological Perspective, in Genocide: An Anthropological Reader, ed. Alexander Laban Hinton (Oxford, UK: Blackwell, 2002), 82.

${ }^{34}$ Martin Shaw, What Is Genocide? (Cambridge: Polity, 2007), 154.
} 
In order to avoid further definitional confusion, this monograph will follow the GPTF practice of using the term genocide to refer to the wider group of crimes that merit international concern. This definition accounts for the complexity of genocide and its tendency to quickly escalate or morph into other kinds of violence. Sociologist Charles Tilly, in his examination of collective violence, noted this link by observing that perpetrators of collective violence frequently shift among types of violence, and alternate between periods of violence and non-violence. ${ }^{35} \mathrm{He}$ argued that such instances of collective violence, in all its various manifestations, are actually a form of contentious politics. He summed up the theme of his work as follows:

Collective violence occupies a perilous, but coherent place in contentious politics. It emerges from the ebb and flow of collective claim making and struggles for power. It interweaves incessantly with nonviolent politics, varies systematically with political regimes, and changes as a consequence of essentially the same causes that operate in the nonviolent zones of collective political life.

Similarly, in his masterwork of military theory, On War, Carl von Clausewitz described war as an extension of politics. It is arguable then that Tilly's work extends the Clausewitzian link between politics and war to other forms of collective violence, to include genocide.

Shaw also examined the linkages between war and genocide and argued that genocide is, in fact, a form of war. Shaw began his argument with the definition of war as a "clash of two organized armed forces that seek to destroy each other's power and especially their will to resist, principally by killing members of the opposing force.” ${ }^{\text {}}$ War tends, however, to escalate beyond the realm of military necessity to involve the killing of both combatants and noncombatants. Shaw called this deliberate extension of war to target the civilian population degenerate war. This logical escalation, which Shaw referred to as a "dialectic between discriminating aims and 2003), 109.

${ }^{35}$ Charles Tilly, The Politics of Collective Violence (Cambridge: Cambridge University Press,

${ }^{36}$ Martin Shaw, War and Genocide: Organized Killing in Modern Society (Cambridge, UK: Polity Press in association with Blackwell, 2003), 5. 
indiscriminate results," ${ }^{37}$ was also noted by Clausewitz when he wrote that "the morale and emotions of the combatants ... might be so aroused that the political factor would be hard put to control them." 38

Shaw described genocide as the destruction of a civilian group by an organized armed force principally by killing members of the civilian group. Civilian groups are then enemies for the organized power that attacks them, and not merely due to their relationship to an armed force. In using this definition of civilian groups as enemies to be destroyed, genocide utilizes the logic of war and can be seen as an extension of degenerate war. ${ }^{39}$ As Shaw described the link in a later publication:

Thus the structure of genocide, as a conflict between armed power organizations and largely unarmed civilian populations, is only a variant of the general structure of armed conflict, distinguished by the fact that in genocide armed power targets violence directly at the unarmed, considered as an enemy in themselves rather than an extension of the armed enemy. And of course genocide does not remain a pure combatant-civilian conflict, but generally tends to partially even up into combatant-combatant conflict, either because a section of the targeted civilian population arms for resistance, and/or because of the intervention of third-party armed actors on the side of the threatened civilian population. ${ }^{40}$

Building on the work of Tilly and Shaw, genocide can be seen as a form of degenerate war resulting from contentious politics. This concept of genocide is compatible with Clausewitz's description of war as "more than a true chameleon that slightly adapts its characteristics to the given case. ${ }^{41}$ Clausewitz stated that war is a paradoxical trinity composed of passion, chance, and reason, which are primarily the concerns of the corresponding social structures of the people,

${ }^{37}$ Shaw, War and Genocide, 25.

${ }^{38}$ Clausewitz, 99.

${ }^{39}$ Shaw, War and Genocide, 5.

${ }^{40}$ Martin Shaw, "The General Hybridity of War and Genocide," Journal of Genocide Research 9, 3 (September 2007): 461-473, http://puj-portal.javeriana.edu.co/portal/page/portal/Facultad\%20de\%20 Ciencias\%20Politicas\%20y\%20Relaciones\%20Internacionales/1documentos/The\%20general\%20hibridity \%20of\%20war\%20and\%20genocide\%5B1\%5D_0.pdf (accessed 15 January 2014).

${ }^{41}$ Clausewitz, 101. 
the army, and the government. As a form of war, Clausewitz's paradoxical trinity can be extended to genocide and its own corresponding social structures of the genocidal population, genocide perpetrators, and genocide leaders (see fig. 2). The following section uses these structures as a means of organizing and understanding the literature on the causes and indicators of genocide. This information on causes and indicators of genocide arranged by the trinity is then used in later sections to develop a ‘Clausewitzian’ framework for genocide prevention.

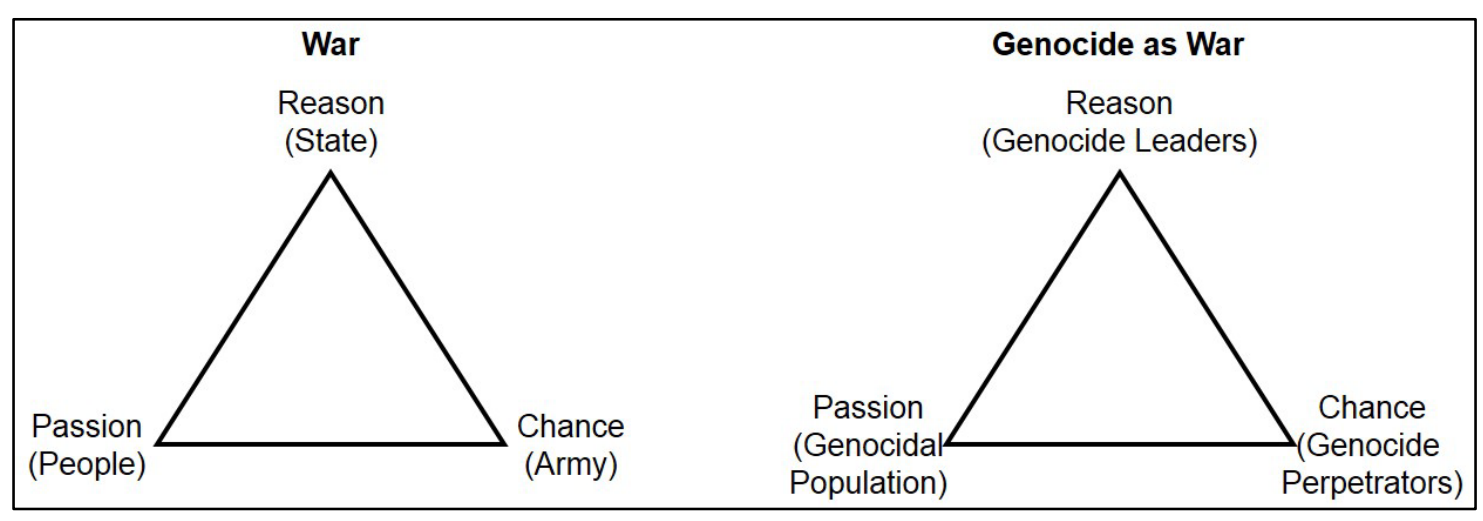

Figure 2: Clausewitz’s Trinity Applied to Genocide

Source: Created by author.

\section{REVIEW OF GENOCIDE CAUSES AND INDICATORS}

\section{Causes and Indicators: The Genocidal Population}

In his book, The Psychology of Genocide: Perpetrators, Bystanders, and Rescuers, psychologist and genocide scholar Steven Baum described genocide researchers as being divided into two groups: those who view genocide as an act instigated by ruling elites from above, and those who view it as rooted in deep hatred bubbling up from below. ${ }^{42}$ This section examines genocide from the latter, bottom-up perspective. As Clausewitz stated, "the passions that are to be

\footnotetext{
${ }^{42}$ Steven K. Baum, The Psychology of Genocide: Perpetrators, Bystanders, and Rescuers
} (Cambridge: Cambridge University Press, 2008), 26. 
kindled in war must be inherent in the people." ${ }^{43}$ This section surveys the literature on the factors that can be said to inflame the passions of the people, causing them to support evil deeds done on their behalf. These factors are common to occurrences of genocide and include the presence of difficult life conditions, the psychological mechanisms that contribute to moral exclusion of others, and certain cultural characteristics found in genocidal societies.

\section{Difficult Life Conditions}

Exposure to difficult life conditions is the first factor that can be said to inflame the passions of the people, and is a common occurrence within societies subjected to genocide. Helen Fein noted the reduction of a state's rank by internal strife or loss in war, thus resulting in a crisis of national identity, as one of four preconditions, intervening factors, and causes that lead towards genocide. ${ }^{44}$ Barbara Harff and Ted Gurr developed a risk assessment model for early warning of genocide that identified a set of international and internal background conditions, intervening conditions, and accelerators that are immediate antecedents of systematic killings. The model listed shifting global alliances, reaction to political upheaval, and international economic status of the regime as international background conditions for genocide. Furthermore, Harff and Gurr noted that political upheaval or ethnic warfare were antecedent to 33 of 35 genocides that began between 1955 and 1996. ${ }^{45}$ Historian Eric Weitz observed that genocides “almost invariably develop in the context of warfare and extreme social and political crisis, when the normal rules of human interaction are suspended and the practice of violence is honored and rewarded." ${ }^{46}$ Weitz

${ }^{43}$ Clausewitz, 101.

${ }^{44}$ Helen Fein, Accounting for Genocide: National Responses and Jewish Victimization During the Holocaust (New York: Free Press, 1979), 9.

${ }^{45}$ Barbara Harff and Robert Ted Gurr, "Systematic Early Warning of Humanitarian Emergencies," Journal of Peace Research 35, no. 5 (September 1988): 553, http://www.jstor.org/discover/10.2307/425699?uid=3739744\&uid=2129\&uid=2134\&uid=2\&uid=70\&uid= 4\&uid=3739256\&sid=21103887135883 (accessed 2 January 2014).

${ }^{46}$ Eric D. Weitz, The Modernity of Genocides: War, Race, and Revolution in the Twentieth 
argued that the revolutionary movements of the twentieth century combined with warfare and race to accelerate the occurrence and scale of genocides. ${ }^{47}$

Psychologist Ervin Staub also stressed the role that difficult life conditions plays in the potential for genocide within a society. Staub related difficult life conditions to his "personal goal theory” as a framework for understanding how people choose violence under certain circumstances. The theory identified four kinds of motives: personal goals, needs, societal rules, and unconscious motivations. Personal goals can be related to the self or related to others through moral values and concern for others' welfare. When a moral motive conflicts with another motive, people use a variety of conflict resolution processes that deactivate moral values or exclude others from the moral realm. Staub theorized that difficult life conditions trigger these psychological processes, causing the affected society to deactivate moral values or exclude others from moral consideration. ${ }^{48}$

Moral Exclusion

Staub is not alone in noting the phenomena of moral exclusion of certain members of society prior to the occurrence of a genocide. Helen Fein lists exclusion from the universe of obligation as the first of her four preconditions, intervening factors, and causes that lead towards genocide. ${ }^{49}$ Gregory Stanton of Genocidewatch.org asserted that genocide is a process that develops over ten stages, the first four of which are concerned with the moral exclusion of

Century, in The Specter of Genocide Mass Murder in Historical Perspective, eds. Robert Gellately and Ben Kiernan (Cambridge: Cambridge University Press, 2003), 56.

${ }^{47}$ Eric D. Weitz, The Modernity of Genocides: War, Race, and Revolution in the Twentieth Century, in The Specter of Genocide Mass Murder in Historical Perspective, eds. Robert Gellately and Ben Kiernan (Cambridge: Cambridge University Press, 2003), 56.

${ }^{48}$ Ervin Staub. “Moral Exclusion, Personal Goal Theory, and Extreme Destructiveness.” Journal of Social Issues 46, no. 1 (Spring1990 1990): 48-55. SocINDEX with Full Text, EBSCOhost (accessed 7 February 2014).

${ }^{49}$ Helen Fein, Accounting for Genocide, 9. 
genocide victims. Stanton's ten stages of genocide include: 1) Classification: Division of the society into "us and them” groups. 2) Symbolization: Giving names or symbols to the classification. 3) Discrimination: The use of law, custom, or political power to deny the rights of other groups. 4) Dehumanization: Denying the humanity of a group. 5) Organization:

Organization of the bureaucracy or perpetrator groups that will carry out genocidal acts.

6) Polarization: Further division of groups from society. 7) Preparation: Perpetrators prepare to carry out collective violence. 8) Persecution: Hostility and ill-treatment of excluded groups.

9) Extermination: Destruction of members of the excluded groups. 10) Denial: Declaring that the genocide did not occur and taking action to ensure the truth is not heard. ${ }^{50}$

Social psychologist James Waller proposed a general explanatory model of how ordinary people commit genocide that also included moral exclusion, along with us-them thinking and blaming the victim, under a broader category of the "psychological construction of other." ${ }^{51}$ The model tied the evolution of human nature, that is, the capacity to do both good and evil, to three proximate influences: the cultural construction of worldview, the psychological construction of other, and the social construction of cruelty. The proximate influence of psychological construction of other and its associated psychological mechanisms merit further explanation.

${ }^{50}$ Gregory H. Stanton, “The Ten Stages of Genocide,” Genocide Watch, http://genocidewatch.org/genocide/tenstagesofgenocide.html (accessed 14 November 2013).

${ }^{51}$ James Waller, Becoming Evil: How Ordinary People Commit Genocide and Mass Killing (Oxford; New York: Oxford University Press, 2007), 196. 


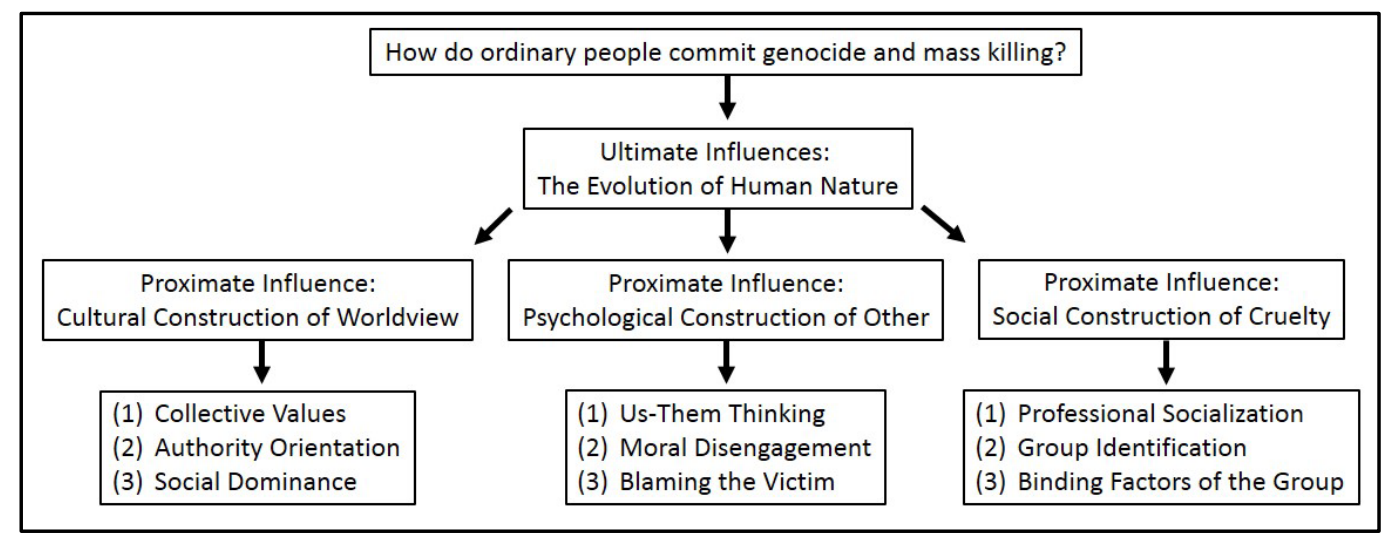

Figure 3: James Waller’s Model of How Ordinary People Commit Genocide and Mass Killing. Source: Waller, 138.

The first mechanism Waller introduced in his concept of the psychological construction of other is that of us-them thinking. This is the mechanism through which humans categorize their kin and social groups by categorizing people as 'us' or 'them.' Waller related this to the Robbers' Cave experiment in which psychologist Muzafer Sherif divided twenty-two, normal, eleven-yearold boys into two randomly assigned groups, and subjected them to a series of competitive activities. Conflict and tension quickly escalated within the two groups, to the point that even noncompetitive activities degraded to insults and fighting. ${ }^{52}$ Waller theorized that the mechanism of us-them thinking has its roots in the psychological adaptations of ethnocentrism, the tendency to focus on one's group as superior to another, and xenophobia, the tendency to fear outsiders. ${ }^{53}$

The concept of us-them thinking is closely tied to the psychological underpinnings of group behavior. French sociologist Gustav Le Bon examined group behavior in his 1896 work The Crowd: A Study of the Popular Mind. Le Bon declared that group members surrender their reasoning ability and become mere extensions of a crude and primal aggregate. As he stated, "In

\footnotetext{
${ }^{52}$ Waller, 198 citing M. Sherif, O. J. Harvey, B. J. White, W. R. Hood, and C. Sherif, Intergroup Conflict and Cooperation: The Robbers' Cave Experiment (Norman: Oklahoma Book Exchange, 1961).

${ }^{53}$ Ibid., 198-201.
} 
crowds, it is stupidity and not mother-wit that is accumulated." 54 Austrian neurologist Sigmund Freud agreed with Le Bon's thesis and expanded upon it with his concept of the primal horde, an explanatory model for group behavior under a leader. ${ }^{55}$ Freud explained that groups are dominated by the unconscious, and an individual's conscience and values are transferred to the leader of a group. ${ }^{56}$ Waller noted that groups tend to be more antagonistic, competitive, and mutually exploitative than individuals, and that they allow for diffusion of responsibility and can suppress individual dissent against wrongdoing; however, he feels that Le Bon's and Freud's views are overly pessimistic. Groups instead act to amplify the views and values of their members. As Waller stated, "it is not the nature of the collective that limits our possibility for cooperative, caring, non-violent relations; it is the nature of the individuals that make up the collective."57

Staub also noted the role that group behavior plays in genocide. Staub described the tendency of people to use trivial or even arbitrary information to divide others into in-groups and out-groups, and then make judgments about the out-groups. Staub cited an experiment in which thirty-two boys were divided into groups and asked to complete an estimation task together. After the task, the boys were told that they belonged to a group of people who tend to overestimate or underestimate when completing such tasks. Each boy was then asked to divide a sum of money between two other boys. The only information the child was given was that one boy was an overestimator and the other was an under-estimator, and that his own money would not be affected. The result of the experiment was that the money was not divided equally, and the boys

\footnotetext{
${ }^{54}$ Gustave Le Bon, The Crowd: A Study of the Popular Mind (Kitchener: Batoche Books, 2001), 17, http://socserv.mcmaster.ca/econ/ugcm/3ll3/lebon/Crowds.pdf (accessed 20 December 2013).

${ }^{55}$ Sigmund Freud, Group Psychology and the Analysis of the Ego, Trans. James Strachey (Vienna, Austria: The International Psycho-Analytical Press, 1922), v, http://www.gutenberg.org/files/35877/35877h/35877-h.htm\#page_001 (accessed 16 December 2013).

${ }^{56}$ Waller, 34-35.

${ }^{57}$ Ibid., 40.
} 
discriminated in favor of others who shared their arbitrary categorization. ${ }^{58}$ Staub explained that this psychological mechanism of creating in-groups and out-groups and then devaluating the outgroups leads to seeing others as threatening or unworthy, loosening the restraints of using violence against them. ${ }^{59}$

Another element of us-them thinking noted by genocide scholars is the concept of the self. Self-concept and self-esteem are important in determining the response to threat or frustration at both the individual and societal level. ${ }^{60}$ At the individual level, a moderately positive self-image is associated with sensitivity; however, at the societal level, both high and low self-esteem can enhance perception of threats. ${ }^{61}$ Staub asserted that this perception of threat could cause societies to turn to violence as they seek to gain that which they think they are deprived. ${ }^{62}$ Waller shares this opinion and based his argument on the research of social psychologist Roy Baumeister. Baumeister showed that perpetrators of violence are usually people with high selfesteem; however, high self-esteem alone is not an indicator of likelihood for violence. Instead, when people with high self-esteem, particularly narcissists, are met with a challenge to their ego, they respond with aggression. This phenomenon also manifests in group behavior, with the group with higher self-esteem generally being more violent than others with lower self-esteem. Baumeister extended this idea of "threatened collective egotism” to the national level by noting, “Feelings of collective superiority are linked to violent, militaristic inclinations, ranging from personal conflicts to nuclear war.”63

\footnotetext{
${ }^{58}$ Ervin Staub, The Roots of Evil: The Origins of Genocide and Other Group Violence (Cambridge, England: Cambridge University Press, 1989), 58, citing H. Tajfel, Social Identity and Intergroup Relations, (Cambridge, England: Cambridge University Press, 1982).

${ }^{59}$ Ibid., 58-62.

${ }^{60}$ Ibid., 54; also see pages 35-36 for an explanation of aggression at the individual level.

${ }^{61}$ Ibid., 55.

${ }^{62}$ Ibid.

${ }^{63}$ Waller, 257, quoting Roy F. Baumeister, Brad J. Rushman, and W. Keith Campbell, “Self-
} 
Returning again to Waller's concept of the psychological construction of other, the second mechanism Waller discussed is that of moral disengagement. In examining the concept of moral disengagement, Waller built on the research of Albert Bandura, a social psychologist at Stanford University. Bondura asserted that people generally refrain from behavior that will violate their moral standards because it will result in self-condemnation; however, those moral standards do not operate unless they are activated. ${ }^{64}$ In order to inhibit activation of moral standards, Waller proposed that people engage in a process of detachment involving the practices of moral justification, dehumanization, and euphemistic labeling of evil actions.

Kuper also examined the role that dehumanization plays in genocide. He defined dehumanization as the denial of human status. Expanding upon this definition and clarifying additional elements, he described the dehumanization process as:

[T] he exclusion from community (and I would add, the denial of a common humanity), and the rejection of individual significance, with its corollaries of the categorization of the target group in pejorative terms and its aggregation of the victims into the anonymity of a collectivized mass. ${ }^{65}$

Kuper also noted the frequent reliance on animal and disease metaphors in the dehumanization process. He cited as examples European settler use of the term, bobbejaan or baboon, in reference to native Africans, and the frequently repeated Nazi description of Jews as cancer. ${ }^{66}$

Daniel Goldhagen also noted the role of dehumanization in genocide. In his book, Worse than War, Goldhagen offered an alternative conceptualization of genocide as a particular form of eliminationism. Goldhagen argued, "When unwilling to come to some form of modus vivendi,

Esteem, Narcissism, and Aggression: Does Violence Result from Low Self-Esteem or Threatened Egotism?,” Current Directions in Psychological Science 9 (2000), 26-29.

${ }^{64}$ Waller, 202, quoting Albert Bondura, "Moral Disengagement in the Perpetration of Inhumanities,” Personality and Social Psychology Review 3 (1999), 193-209, and "Exercise of Human Agency through Collective Efficacy,” Current Directions in Psychological Science 9 (June 2000), 75-78.

\footnotetext{
${ }^{65}$ Kuper, Genocide, 87.

${ }^{66}$ Ibid., 88-91.
} 
groups ... deal with populations they have conflict with ... by seeking to eliminate them or to destroy their capacity to inflict putative harm.” He argued that this is accomplished through five forms of elimination: transformation, repression, expulsion, prevention of reproduction, and extermination, the category to which genocide belongs. In his examination of eliminationist extermination, or genocide, Goldhagen analyzed the role of dehumanization and argued that the dimensions of dehumanization and demonization cause perpetrators to conceive victim groups differently. He advanced a simple matrix containing the separate dimensions of demonization and dehumanization based on the perception of the perpetrator group. The resulting categories he labeled 1) existential enemies, 2) heretics, 3) subhumans, and 4) demons. These categories can then be applied to the victim groups through dehumanizing or demonizing ideas and language to instigate eliminationist attacks. As Goldhagen explained, "if a being is like a disease, or a bug . . . if a being willfully threatens all that is good . . . if a being is evil incarnate, then it follows that one must eradicate the disease, squash the bug . . . destroy the threat, or extirpate the evil.”67

Table 1: Goldhagen's Patterns of Dehumanization and Demonization of Eliminationist Victims.

\begin{tabular}{|l|l|l|}
\hline & Non-Demonized & Demonized \\
\hline Non-Dehumanized & Existential Enemies & Heretics \\
\hline Dehumanized & Subhumans & Demons \\
\hline
\end{tabular}

Source: Goldhagen, Worse than War : Genocide, Eliminationism, and the Ongoing Assault on Humanity (New York: Public Affairs, 2009), 14, 331.

Lastly, the third mechanism Waller discussed in his concept of the psychological construction of other is the act of victim blaming. Following the mechanisms of us-them thinking and moral disengagement that de-humanize groups and permit or even encourage violence against them, victim blaming provides justification for evil acts that are committed. Waller asserted that

\footnotetext{
${ }^{67}$ Daniel Jonah Goldhagen, Worse than War : Genocide, Eliminationism, and the Ongoing Assault on Humanity (New York: PublicAffairs, 2009),14, 331.
} 
victim blaming is rooted in just world thinking and scapegoating. Just world thinking is attributed to social psychologist Melvin Lerner and is the idea that the world is essentially just and whatever happens to people is what they deserve. ${ }^{68}$ Just world thinking, when combined with us-them thinking and moral disengagement, "allows us to retain a sense that we are just people living in a just world - a world where people get what they deserve,” despite the horrible nature of the atrocities they have endured. ${ }^{69}$ Scapegoating, on the other hand, may be used to direct aggression on a group when a larger group is faced with frustration from a cause that is either too vague or too intimidating to confront. ${ }^{70}$

Staub also examined scapegoating, particularly as it relates to personal goal theory. He argued that scapegoating was a method of coping when personal goals are not met due to the fault of one's own group, a powerful aggressor, or when the cause cannot be identified. By assigning blame to previously devalued out-groups, in-groups are able to diminish their sense of guilt over their situation and elevate their self-esteem. ${ }^{71}$ As an example, Staub cited the words of Tertullian, a Roman Christian author, regarding the Romans:

They take the Christians to be the cause of every disaster to the state, of every misfortune to the people. If the Tiber reaches the wall, if the Nile does not reach the fields, if the sky does not move or if the earth does, if there is a famine, or if there is a plague, the cry is at once, "The Christians to the Lions."72

Leo Kuper described the main elements of a scapegoat type of genocide. The first is an identifiable and differentiated group within a society. He noted that vulnerability or inability of a group to defend itself is also a vital element. Material advantages are typically also at stake.

\footnotetext{
${ }^{68}$ Waller, 213, citing Melvin J. Lerner and Carolyn Simmons, “Observer’s Reaction to the 'Innocent Victim': Comapssion or Rejection,” Journal of Personality and Social Psychology, 4 (1966), 203-210.

${ }^{69}$ Ibid., 213.

${ }^{70}$ Ibid., 218.

${ }^{71}$ Staub, The Roots of Evil, 48-49.

${ }^{72}$ Ibid., 49.
} 
Negative stereotypes and vilifying propaganda are then directed at the group, typically to dehumanize the members. The group is then victimized as a surrogate for the underlying issues causing frustration. ${ }^{73}$

\section{Cultural Characteristics}

In addition to the individual psychological mechanisms that contribute to genocide, scholars have noted that certain cultural characteristics can help inflame the will of the people and contribute to their support of genocide. These characteristics include the degree to which a society is pluralistic, and the society's orientation towards authority, social dominance, and collectivism. The first of these, pluralism within a society, or the degree to which differences in opinions and beliefs are present in a society, is disputed. Staub argued that few, if any, monolithic societies remain, and that pluralism within a society causes the development of mechanisms to resolve disputes over differing opinions. ${ }^{74}$ He stated that "moral development is advanced . . . because [pluralism] requires people to resolve conflicting standards and expectations." ${ }^{75}$ Kuper advanced a slightly different view of a pluralistic society and claimed that it provided a “structural base” for genocide. Kuper used a more extreme definition of pluralistic society borrowed from J. S. Furnivall, which described societies with "persistent and pervasive cleavages” between its groups. ${ }^{76}$ He argued that these cleavages, when present in an extreme form, may lead to discrimination and exclusion that creates the structural foundation for genocidal acts. ${ }^{77}$ The difference in Staub’s and Kuper's arguments lies more in the absence of conflict resolution mechanisms within a society than in the actual plurality of opinions. It can be

\footnotetext{
${ }^{73}$ Kuper, Genocide, 43.

${ }^{74}$ Staub, The Roots of Evil, 62-63.

${ }^{75}$ Ibid., 63.

${ }^{76}$ Kuper, Genocide, 58.

${ }^{77}$ Ibid., 57-59.
} 
inferred, therefore, that the propensity for genocide within a pluralistic society increases when extreme inequality between groups is allowed to fester.

The orientation towards authority of members of a culture, or their propensity for obedience to authority figures, is also a contributing factor to a society's propensity for genocide. The research on the link between authority orientation and genocide finds its roots in the search by psychiatrists and scholars for abnormal psychological traits that were thought to be possessed by Nazis that predisposed them to blind allegiance and willful violence. One such psychiatrist was Henry Dicks, also a British Army officer, who was tasked by the British military to care for captured prisoners of war, a group that included the deputy head of the Nazi party, Rudolph Hess. In his report of personality traits of German prisoners, Dicks described the German character as “over-respectful to authority and anxious to impress. . . . Conformity and 'loyalty’ . . . are rated among the highest virtues, and demonstratively stressed in home and institutional life, almost synonymous with 'honour' on the one hand and with unquestioning obedience on the other."78

After the war, researchers at the University of California, Berkeley attempted to determine the characteristics that make up the "potentially fascistic" individual that is susceptible to Nazi propaganda, which they called the authoritarian personality. ${ }^{79}$ Their findings were published in a book called The Authoritarian Personality that described nine clusters of personality traits that predisposed an individual to fascistic or anti-democratic propaganda, which they called the Fascism Scale, or F-Scale. The nine F-scale traits included:

1. Conventionalism. Rigid adherence to conventional, middle-class values.

2. Authoritarian submission. Submissive, uncritical attitude toward idealized moral authorities of the in-group.

3. Authoritarian aggression. Tendency to be on the lookout for, and to condemn, reject, and punish people who violate conventional values.

${ }^{78}$ Henry Dicks, “Dicks on Germany Personality 2,” The Pursuit of the Nazi Mind, http://www.bbk.ac.uk/thepursuitofthenazimind/HD.php (accessed 21 January 2014).

${ }^{79}$ Theodor W. Adorno, The Authoritarian Personality (New York: Harper, 1950), 1, http://www.ajcarchives.org/main.php?GroupingId=6490 (accessed 23 January 2014). 
4. Anti-intraception. Opposition to the subjective, the imaginative, the tender minded.

5. Superstition and stereotypy. The belief in mystical determinants of the individual's fate; the disposition to think in rigid categories.

6. Power and "toughness." Preoccupation with the dominance-submission, strong-weak, leader-follower dimension; identification with power figures; overemphasis upon the conventionalized attributes of the ego; exaggerated assertion of strength and toughness.

7. Destructiveness and cynicism. Generalized hostility, vilification of the human.

8. Projectivity. The disposition to believe that wild and dangerous things go on in the world; the projection outwards of unconscious emotional impulses.

9. Sex. Exaggerated concern with sexual "goings-on." 80

Political theorist Hannah Arendt also noted the strong orientation towards authority displayed by Adolph Eichmann, the subject of her book, Eichmann in Jerusalem. In this individual account of the trial and psychology of senior Nazi SS officer and holocaust organizer Adolph Eichmann, she wrote that "whatever he did he did, as far as he could see, as a law-abiding citizen. He did his duty, as he told the police and the court over and over again; he not only obeyed orders, he also obeyed the law.” Eichmann was thus so sure of the infallibility of authority that he willingly took actions that were morally reprehensible. Eichmann's sense of obedience is just one of many traits that Arendt used to dispel the popular concept of the abnormal "Nazi mind" and instead portrayed her subject as possessing what most would consider an air of normalcy.

Contemporary genocide scholars have also studied the link between authority among members of a society and the society’s propensity for evil acts. Staub built upon the idea of the authoritarian personality put forth by Adorno et al. to understand what he calls "authority orientation,” which refers to a person's “tendency to order the world and relate to people according to their position and power in hierarchies." ${ }^{81}$ He argued that child-rearing practices in

${ }^{80}$ Theodor W. Adorno, The Authoritarian Personality (New York: Harper, 1950), 228, http://www.ajcarchives.org/main.php?GroupingId=6490 (accessed 23 January 2014).

${ }^{81}$ Staub, The Roots of Evil, 75. 
pre-war Germany led to a stronger authority orientation and a tendency to devalue those with less power. ${ }^{82}$ Waller expanded on Staub's emphasis on child-rearing and the family by drawing on the work of sociologist Daid Norman Smith to illustrate the effect that roles in the family can have on violence in a society. Societies in which the children are seen as helpers and praised for their obedience towards an authoritarian father, as was the case in Rwanda, are more prone to intense violence. ${ }^{83}$ Waller also noted the tendency for authority orientation to be reinforced by other values such as collectivism, nationalism, and religion. Waller showed that a history of authoritarian structure within a culture, such as in Rwanda and Cambodia, can be leveraged by the proponents of other values to instigate violence.

Waller expanded on the link between collectivist cultures and genocide. He described collectivist cultures as those that place an emphasis on the group and possess collectivist values such as "obedience, conformity, tradition, safety, and order." ${ }^{84}$ Individualist societies, for which he offers the United States as an example, place emphasis on the individual and possess the individualistic values of "personal independence, freedom of choice, personal uniqueness, personal happiness, and personal achievement.”85 Waller stated that these collectivist values within a society contribute to a concept of self that it based on social identities, or membership within a group. This emphasis on social identity can then lead to a stronger sense of in-group and out-group. He argued that this sense of in-group and out-group resulted in four effects: assumed similarity effect, in which group members are perceived as more similar than out-group members; out-group homogeneity effect, in which members of the out-group are seen as alike; accentuation effect, an overestimation of the differences between in-group and out-group; and in-group bias,

\footnotetext{
${ }^{82}$ Staub, The Roots of Evil, 73-75.

${ }^{83}$ Waller, 180, citing David Norman Smith, “The Psychocultural Roots of Genocide.”

${ }^{84}$ Ibid., 173.

${ }^{85}$ Ibid.
} 
the previously mentioned tendency to act in favor of members of the in-group. These collectivistic effects combine to enhance the conditions for genocidal acts. As Waller summarized, "At the extreme, collectivistic values may even translate into collective violence or genocidal imperative as they are used to forge in-group solidarity and undermine the normal inhibitions against killing out-group strangers.”86

In addition to collectivism and authority orientation, society's propensity for genocide is increased by the presence of social dominance. Social dominance is the extent to which groups view themselves as superior to others. In order to reduce conflict between groups, social dominance theory states that societies promote ideologies that legitimize the superiority of one group over other groups. ${ }^{87}$ At the individual level, Pratto et al. introduced social dominance orientation (SDO) as a measure of individual attitude towards intergroup relations. They noted that people with high SDO tend to favor what they called "hierarchy-enhancing” ideologies and are more prone to racism, nationalism, and cultural elitism. ${ }^{88}$ Waller posited that these same ideologies that reinforce social dominance within a society also combine with the other determinants of world-view, which include authority orientation and collective values, to create the cultural propensity for genocide within a society. ${ }^{89}$

Similarly, Staub advanced the notion of a "culture of antagonism” that can manifest at the national level to instigate war between nations through manipulation of existing ideologies. He described this culture of antagonism and the manner in which it affects a society as follows:

Conflicts will arise, and real conflict will be magnified, as we respond not to the issues at hand or the people on the other side, but to the stereotypes and negative

\footnotetext{
${ }^{86}$ Waller, 178.
}

${ }^{87}$ Felicia Pratto, James Sidanius, Lisa M. Stallworth, and Bertram F. Malle, "Social dominance orientation: A personality variable predicting social and political attitudes," Journal of Personality and Social Psychology 67, no. 4 (1994): 741-763.

${ }^{88}$ Pratto, Sidanius, Stallworth, and Malle, “Social dominance orientation,” 741-763.

${ }^{89}$ Waller, 183-189. 
images that we hold. An ideology of antagonism may evolve out of differences in values, beliefs, and ways of life, devaluation, and a past history of antagonism. It encodes the negative evaluation and identifies the other as a threat to the wellbeing, security, and even survival of one's group. It may lead to a belief that superiority is required for security and a wish to diminish, subdue, and in extreme cases exterminate this enemy. ${ }^{90}$

Similar to social dominance theory, the basis of the culture of antagonism is the reliance on existing ideologies and legitimizing myths to justify the superiority of one group over another and the aggression that may result from such beliefs.

Social dominance theory and the culture of antagonism are closely associated with the last, and arguably best-known, cultural precursor of genocide within a society that is included in this discussion, which is the presence of extraordinary ideology. An examination of the literature of genocide scholars will invariably touch on ideology and the different theories of its connection to genocide. ${ }^{91}$ As Kuper postulated, genocides prior to the twentieth century may have been nonideological, but instances of genocide in recent history have been associated in some manner with ideology. Chalk and Jonassohn listed the implementation of ideology as one of the four potential motives in their motive-based typology of genocide. ${ }^{92}$ Fein noted the prominent role of ideology in her summary of the preconditions of genocide in her book, Accounting for Genocide. She wrote that it is a "necessary, but not sufficient" precondition for genocide that a group rising to power “adapts a new political formula to justify the nation's domination and/or expansion, idealizing the singular rights of the dominant group."93 Fein added quantitative weight to her

\footnotetext{
${ }^{90}$ Staub, The Roots of Evil, 251.
}

${ }^{91}$ Kuper, Genocide, 54-55, discussed the role of ideology in a plural society; also see Waller, Becoming Evil, 41-53, for a refutation of Goldhagen; Staub, Roots of Evil, 50; Chalk and Jonassohn, 29; Fein, Accounting for Genocide, 9, a for discussion of the preconditions for genocide; Ibid., 19-21, for the role of ideology in the Nazi rise.

${ }^{92}$ Chalk and Jonassohn proposed a typology based on the motives of the perpetrator. They classified genocides on the basis of the motive to: 1) eliminate a real or potential threat; 2) spread terror among real or potential enemies; 3 ) acquire economic wealth; and 4) implement a belief, theory, or ideology. Chalk and Jonassohn, 29.

\footnotetext{
${ }^{93}$ Fein, Accounting for Genocide, 9.
} 
argument by including her analysis of data highlighting the positive correlation between Jewish victimization and pre-war anti-Semitism in Nazi-controlled Europe; even with comparatively less Nazi control, highly anti-Semitic states produced nearly four times as many victims as less antiSemitic states. ${ }^{94}$

In his exhaustive world history of genocide, Blood and Soil, historian Ben Kiernan noted that episodes of genocide have common aspects of ideology. He grouped these aspects into broad themes, which included racism and religious prejudice, cults of antiquity, cults of agrarianism, and territorial expansionism. The first of these, racism and religious prejudice, are phenomena lacking material basis, and Kiernan notes that they are flexible in the way in which they manifest. They can arise from the perception of a victim group's current inferiority, its historical superiority and subsequent fall, or even on threat from a group’s current superiority. Cults of antiquity are groups fixated on the returning to some former state of purity or order. They generate thoughts of superiority or loss of historical standing that transcend time and geography. Kiernan offered the example of Hitler's view of Sparta as an ideal racialist state. Cults of agrarianism lionize the rural members of society, often victimizing racial or ethnic members of society relegated to urban areas or historically barred from land ownership. Lastly, territorial expansion manifests as a societal predilection for increasing territory due to scarcity or economic competition, regardless of whether it is being cultivated by indigenous groups. ${ }^{95}$

In his book, Hitler's Willing Executioners, Goldhagen stressed the importance of ideology within German society as a source of motivation for the Holocaust. Goldhagen stated that a virulent strain of extraordinary ideology, the aforementioned "eliminationist antiSemitism,” was a fundamental part of German national identity, and the most significant factor

${ }^{94}$ See Figue 3-4, Jewish Victimization Graphed as a Function of Pre-war Anti-Semitism and SS Grip over the State in 1941. Fein, Accounting for Genocide, 81.

${ }^{95}$ Ben Kierman, Blood and Soil: a World History of Genocide and Extermination from Sparta to Darfur (New Haven: Yale University Press, 2007), 2-33. 
that contributed to genocide. Goldhagen argued that German anti-Semitism grew out of medieval Christianity's antagonistic view of Judaism and transformed in the nineteenth century into a racial anti-Semitism that permeated Germany's national culture. This culture of hatred fostered support for genocidal acts against the Jewish population. ${ }^{96}$

Goldhagen's view of extreme ideology as the singular cause of genocide is not widely shared by other genocide scholars. Waller disagreed that anti-Semitism in early twentieth-century Germany was notably worse than in other parts of Europe. He noted that Germany was actually a hospitable place for Jews, in which they possessed civil rights and were civically overly influential. Additionally, he noted that the Nazis actually chose the politically expedient tactic of downplaying the Jewish issue prior to the 1930 election in which they rose to power.

Furthermore, he argued that there have simply been too many other recent instances of genocide that were unrelated to anti-Semitism to lend credibility to a mono-causal explanation of ideology. Instead, Waller offered that it may have been indifference brought on by "moderate antiSemitism” that operated as one of a number of causes for the Holocaust. ${ }^{97}$ Similarly, Christopher Browning, historian and author of Ordinary Men, a study of the executioners from German Reserve Police Battalion 101, argued that anti-Semitism did not play the central role that Goldhagen claimed. Browning noted that members of the battalion had shown reluctance to kill Jews at times while they had not shown reluctance to kill Poles. ${ }^{98}$ Furthermore, Browning emphasized the results of the interrogations of the Luxemburger members of the battalion, those from a different ideological background than the Germans, yielded results similar to the

\footnotetext{
${ }^{96}$ Daniel Jonah Goldhagen, Hitler's Willing Executioners: Ordinary Germans and the Holocaust (New York: Knopf: Distributed by Random House, 1996) 3-128.

${ }^{97}$ Waller, 40-51.

${ }^{98}$ Christopher R. Browning, Ordinary Men: Reserve Police Battalion 101 and the Final Solution in Poland (New York: HarperCollins, 2001), 211-213.
} 
Germans. ${ }^{99}$ Instead of eliminationist anti-Semitism causing genocide, Browning suggested that Germans may have been drawn to anti-Semitism as a result of the popularity of Nazism. ${ }^{100}$ This view of extraordinary ideology is similar to that of Valentino, who argued that ideological mass killings fall under a broader category that he calls dispossessive killings, which aim to strip groups of "their possessions, their homes, or their way of life." ${ }^{101}$ In his top-down view of genocide, ideological killing is not an end unto itself, but a product of a strategy to meet a leader's political goals. While the extent of the causal role that extraordinary ideology plays in genocide will likely continue to be debated, it can be concluded that ideology is an important factor contributing to genocide.

In conclusion, this section has shown that certain factors common to occurrences of genocide are necessary to mobilize the will of the people. These factors include the presence of difficult life conditions, the psychological mechanisms that contribute to moral exclusion of others, and certain cultural characteristics found in genocidal societies. Genocide prevention efforts aimed at the genocidal population should counter these mechanisms, an objective which is addressed in later sections of this monograph. The following sections examine the causes and indicators that relate to the remaining elements of Clausewitz's paradoxical trinity, which are genocide perpetrators and genocide leaders.

\section{Causes and Indicators: Perpetrators of Genocide}

The previous section examined the environmental and psychological factors common to societies plagued by genocide. These factors alone, however, will not result in mass killings. Genocide requires a group of perpetrators who will follow through with the gruesome act of mass

\footnotetext{
${ }^{99}$ Browning, 209.

${ }^{100}$ Ibid., 198.

${ }^{101}$ Benjamin A. Valentino, Final Solutions: Mass Killing and Genocide in the Twentieth Century (London: Cornell University Press, 2005), 71.
} 
killing. Clausewitz argued that the army at war is to be concerned with the "play of courage and talent . . in the realm of probability and chance.” ${ }^{102}$ The one-sided nature of genocide results in a different manifestation of courage and chance, one in which psychology and probability are not aimed at overthrowing the enemy, but at overcoming the inhibitions against murder possessed by most people. This section examines the literature on perpetrators of genocide to reveal how socalled normal people can overcome those inhibitions and become mass killers.

The obvious starting point in understanding perpetrators is to answer the question of where perpetrators come from. That is, are they simply monsters reacting to the ideal conditions for genocide, creating a system of self-selection for the role of genocide perpetrator? Steven Baum offered a model of genocide roles based on emotional maturation of an individual that attempted to answer this question. Baum's model suggested that people with low emotional maturation, the 15 to 20 percent of the population whose identity is shaped mostly by the group or collective, are likely to be perpetrators when raised in a culture of hate. ${ }^{103}$ Similarly, Goldhagen argued that normal Germans were willing to become perpetrators of genocide because of a powerful belief in an eliminationist form of anti-Semitism. Stated simply, "the perpetrators, having consulted their own convictions and morality and having judged the mass annihilation of Jews to be right, did not want to say 'no."”104 Waller and Browning disagreed with Goldhagen’s argument, and both devoted a significant number of pages in their respective books to a rebuttal of Goldhagen, insisting that other factors are involved in perpetrator behavior. As Browning noted, Battalion 101 was composed of reserve officers and conscripts selected after the majority of men had gone to war, and as such, should have resulted in a less than average number of

${ }^{102}$ Clausewitz, 101.

${ }^{103}$ Steven K Baum, The Psychology of Genocide: Perpetrators, Bystanders, and Rescuers (Cambridge; New York: Cambridge University Press, 2008), 94-110.

${ }^{104}$ Goldhagen, Hitler's Willing Executioners, 3. 
violent members. ${ }^{105}$ Furthermore, while Staub recognized that some self-selection of perpetrators may occur, he argued that all people have the capacity to progress along a "continuum of destruction” that ends in violence. ${ }^{106}$ These arguments suggest self-selection alone is not enough to explain perpetrator violence and other factors are at play.

The next obvious question about perpetrators is to what extent obedience to authority plays in their actions, and whether blindly following orders can explain perpetrators' heinous acts. This was the argument repeatedly advanced by Eichmann as he argued that he was following both his orders and the law, practicing what he called "the obedience of corpses." ${ }^{\text {"107 }}$ Obedience to authority obviously plays a large role in human social behavior, a phenomenon illustrated in Milgram's famous obedience experiments. In an effort to understand how the Nazis achieved such large-scale obedience, Milgram designed an experiment to study what he called "destructive obedience.” ${ }^{108}$ In the experiment, subjects were told that they would be participating in an experiment on learning; they were to administer electric shocks to another participant in a separate room when that participant failed to correctly recall a pair of memorized words. The other participant and the administrator asking the questions were actually actors supporting the experiment and the shocks were simulated. The machine that the subjects used to administer the shocks had a series of switches labeled with voltage levels and grouped by severity of shock, the worst of which was beyond "severe shock," simply marked "XXX.” The subjects were to increase the severity of shock each time the other participant failed to correctly answer the

\footnotetext{
${ }^{105}$ Browning, 169.

${ }^{106}$ Staub, The Roots of Evil, 13.

${ }^{107}$ Hannah Arendt, Eichmann in Jerusalem; a Report on the Banality of Evil (New York: Viking

${ }^{108}$ Milgram, Stanley, "Behavioral Study of Obedience,” Journal of Abnormal Psychology, 67, (1963): 371. Bobbs-Merrill Reprint Series in the Social Sciences, http://www.columbia.edu/cu/psychology/terrace/w1001/readings/milgram.pdf (Accessed 12 December
} Press, 1963), 120. 2013). 
question. Milgram also conducted a survey in conjunction with the obedience experiment in which the experiment design was described to a group of psychology students at Yale University, who were asked to estimate how often the participants would proceed to the end of the shock series. At the conclusion of the experiment, all of the participants went beyond the survey’s predicted break-off point of 300 volts, and twenty-six of the forty participants obeyed the orders of the experimenter and administered the maximum voltage. ${ }^{109}$

While the Milgram experiments show the strong effect that authority has on obedience, Waller argued that they do not completely answer the question of how perpetrators can commit violence. He cited four instances in which the experiments did not correspond to genocide: 1) participants were unsure of the consequences of their actions; 2) participants had no previous exposure to the victims and were opposed to causing harm; 3) participants were conflicted over their actions; and 4) participants had little time to consider their actions. ${ }^{110}$ Similarly, Browning noted that the actions of Reserve Battalion 101 at Józefów supported some of Milgram’s conclusions on obedience to authority, but the pressures of conformity proved the stronger source of motivation. ${ }^{111}$ In conclusion, obedience to authority obviously plays a role in perpetrator behavior, but does not offer a singular explanation for perpetrator acts of violence.

As described in the previous section, Waller offered a model of how ordinary people commit genocide based on three proximate influences: the cultural construction of worldview, the psychological construction of other, and the social construction of cruelty. The first two of these proximate influences were described in the previous section on the affected population; the latter is concerned primarily with perpetrators. Waller's concept of the social construction of cruelty examines what he called the "horizontal context" in which perpetrators act - the situational

\footnotetext{
${ }^{109}$ Milgram, 376.

${ }^{110}$ Waller, 111-112.

${ }^{111}$ Browning, 171-176.
} 
factors that allow perpetrators to "initiate, sustain, and cope with their acts of cruelty." 112 Waller grouped these situational factors into three groups of phenomena that contribute to the social construction of cruelty: professional socialization, group identification, and binding factors of the group. ${ }^{113}$ While Waller's concept of the social construction of cruelty is intended as one of three influences that contribute to a holistic view of how people can commit atrocities, his categorization of phenomena contributing to the social construction of cruelty aligns very well with the literature on influences of genocide perpetrators. This section leverages his categories for the discussion of factors contributing to genocide perpetrators and introduces additional sources relevant to the discussion.

\section{Professional Socialization}

The first of Waller's phenomena that contribute to the social construction of cruelty is what he calls professional socialization. Professional socialization is the process through which an initiate to a group, military or paramilitary for this discussion, comes to view the group as legitimate. Behaviors are socialized, norms are reinforced, and commitment to the group is bolstered. Waller argued that there are three mechanisms that contribute to professional socialization of violent behaviors: escalating commitments, ritual conduct, and the merger of the role and the person. ${ }^{114}$ These mechanisms are examined in the following paragraphs.

The first mechanism that contributes to professional socialization is that of escalating commitments, or the use of small incremental steps to persuade a potential perpetrator to commit violent acts. The use of escalating commitments rests on the tendency of people to react favorably to a larger request after first agreeing to one or more smaller requests, what social psychologists

\footnotetext{
${ }^{112}$ Waller, 230.

${ }^{113}$ Ibid., 231.

${ }^{114}$ Ibid., 232.
} 
refer to as the "foot-in-the-door phenomenon." "115 Staub similarly referred to this tendency as “steps along a continuum of destruction” and described its role in the progression from antiSemitic actions in Nazi Germany. Following the rise of Hitler, the Nazis progressed incrementally from exclusionary actions such as removal from jobs, to mass relocation, then to the euthanasia program for handicapped and mentally ill, and finally to extermination and the Final Solution. ${ }^{116}$

In his article, On Killing and Morality, sociologist Harald Welzer described an individual account of escalating commitment among members of German Police Battalion 45. The Battalion's first order of violence against Jews took place near Berdichev, Ukraine. Walzer quoted one gunner’s recollection of the event, “As far as I can remember the first operation, it was like this: we had to report early. The company chief, Paschke, then announced to the company that the company had to carry out an operation from the SS. He further told us that we had to get the Jews together, and then we'd find out the rest." ${ }^{\text {"117 }}$ Upon gathering the victims near a prepared site, members of the Battalion were assigned ditches. Another participant in the event was quoted, "We stood right near a ditch. Here Klamm now designated me as a gunner ... When the first Jews went by me into the ditch, Klamm grabbed the Jews by the neck . . . and said, more or less, 'That's where you need to shoot'.” The first gunner again described the situation: "Hardly had we reached the ditch when the first Jews arrived. We gunners looked at each other, because none of us knew what we were supposed to do or how and in what way the Jews were to be shot.”

${ }^{115}$ Waller, 233; also see Jonathan L. Freedman and Scott C. Fraser, “Compliance Without Pressure: the Foot-in-the-Door Technique,” Journal of Personality and Social Psychology 4, No. 2 (1966): 195-202.

${ }^{116}$ Staub, Roots of Evil, 79-88, perpetrator and bystander steps along a continuum of destruction; Ibid., 117-121, Nazi rule and steps along the continuum of destruction.

${ }^{117}$ Harald Welzer, On Killing and Morality: How Normal People Become Mass Murderers, in Ordinary People as Mass Murderers, Perpetrators in Comparative Perspectives, eds. Olaf Jensen and ClausChristian W. Szejnmann (Houndmills, Balsingstoke, Hampshire: Palgrave Macmillan, 2008), 173, referencing Harald Welzer, Täter. Wie aus ganz normalen Menschen Massenmörder warden (Frankfurt/Main, 2005), 136. 
The gunner then described the final step in the gruesome act, in which Klamm had to again show where to shoot and then actually demonstrate where to shoot before the other gunners joined in. ${ }^{118}$ This example illustrates the escalation of commitment, in this instance an incremental progression along a path towards violence in which the act of killing was separated by time and logic from the actual order to kill.

The second mechanism that Waller argued contributes to professional socialization is that of ritual conduct. He described ritual conduct as "persistent indulgence in apparently noninstrumental exercises - exercises that consume radically limited energies and resources, not only of the victims, but also of the perpetrators themselves." ${ }^{119}$ In short, they are rituals with no logic other than the psychological support of the perpetrators. Waller noted the use of overwrought disciplinary procedures in Nazi concentration camps such as “roll calls, camp parades, meaningless physical exercises, and the stripping and beating of victims already marked for death” as examples of ritual conduct used to maintain Nazi belief in the importance of their mission. Waller also noted that these rituals can take on the form of macho competitions, such as an example he provided from an 1864 account of three frontier soldiers competing over who could strike a small child at seventy-five yards with their rifles. ${ }^{120}$ Staub also noted the use of rituals to increase commitment among members of a group as part of his concept of progression along a continuum of destruction. As he explained, “[g]iving oneself over to the group and acting in unison with others result in a loss of independent personal identity and individual responsibility and in the loosening of moral constraints.”121

\footnotetext{
${ }^{118}$ Welzer, 138.

${ }^{119}$ Waller, 234.

${ }^{120}$ Ibid., 235.

${ }^{121}$ Staub, The Roots of Evil, 124.
} 
The final mechanism that Waller proposed contributes to professional socialization is the merger of role and person. This is the tendency of an individual to internalize certain behaviors associated with a role after acting in the role for a length of time. Waller argued that the mechanism that causes a merger of role and person in genocide is the same as that which is behind the famous Stanford Prison Experiment. In this experiment, psychologist Philip Zimbardo and a group of Stanford University researchers assembled a group of college student volunteers to play the roles of prisoners and prison guards in a mock experiment. The participants were continuously monitored and interviewed, and were provided questionnaires throughout the experiment. As the experiment progressed, interactions between the guards and prisoners became increasingly hostile, to the point that the experiment was terminated early due to the intense reaction of the participants. Zimbardo described the extent to which the participants succumbed to the roles: "[t]he prisoners experienced a loss of personal identity and the arbitrary control of their behavior, which resulted in a syndrome of passivity, dependency, depression, and helplessness. In contrast, the guards (with rare exceptions) experienced a marked gain in social power, status, and group identification, which made role-playing rewarding." ${ }^{\text {"122 }}$ Extending the results of the experiment to genocide, Waller explained that "brutality can be a consequence, not only a cause, of being in a duly certified and legitimized social hierarchy committed to extraordinary evil.”123 Additionally, Browning confirmed similarities between the Zimbardo experiment and the behaviors of members of Reserve Police Battalion 101. In the experiment, the guards' behavior could be divided into groups as “cruel and tough, tough but fair, and good.” Similar groupings

\footnotetext{
${ }^{122}$ Philip Zimbardo, Craig Haney, and Curtis Banks, “Interpersonal Dynamics in a Simulated Prison,” International Journal of Criminology and Penology 1 (1973): 69.

${ }^{123}$ Waller, 237.
} 
occurred among the Battalion members on the basis of whether they were initially willing to kill. ${ }^{124}$

Group Identification

Waller listed group identification as the second of the three phenomena that contribute to the social construction of evil. He stated that the same psychological factors that predispose a population to genocidal acts - us-them thinking and collectivistic values - also contribute to the propensity for perpetrators to commit violent acts. Waller argued that there are two mechanisms "that extend and amplify the power of group identification:” repression of conscience and rational self-interest. ${ }^{125}$

Repression of conscience is a manner of ignoring the normal intuition or judgment against committing acts that are morally reprehensible. Waller asserted that repression of conscience as a factor of group identification allows a situation in which "outside values are excluded and locally generated values dominate." ${ }^{126}$ Waller provided several methods through which conscience was repressed among Nazi perpetrators. One of these was controlling information so that only perpetrators of violence were aware of the violent actions and, conversely, ensuring that those unfortunate people who were informed, in turn, became perpetrators. ${ }^{127}$ Another method of conscience repression used by Nazis that Waller listed was the use of intoxication. Following the massacre at Józefów, Browning described how members of Reserve Battalion 101 used alcohol for coping: "When the men arrived at the barracks in

\footnotetext{
${ }^{124}$ Browning, 169.

${ }^{125}$ Waller, 243.

${ }^{126}$ Ibid., 243.

${ }^{127}$ Ibid., 243, citing Raul Hilberg, The Destruction of the European Jews, Revised and Definitive Edition, 3 vols. (New York: Holmes and Meier, 1985), 23.
} 
Biłgoraj, they were depressed, angered, embittered, and shaken. They ate little, but drank heavily. Generous quantities of alcohol were provided, and many of the policemen got quite drunk.” 128

Waller also noted two mechanisms that work in social context to facilitate repression of conscience: diffusion of responsibility and deindividuation. Deindividuation is the use of uniformity among members of a group that can contribute to increased aggression and allow group absolution of violent acts. ${ }^{129}$ Diffusion of responsibility is the division of blame among many members of a group that absolves an individual member of feelings of guilt or regret. Diffusion of responsibility and other related ideas are discussed by a number of genocide scholars and warrants additional discussion here.

Waller ties diffusion of responsibility to the "bystander effect," introduced by John Darley and Bibb Latane. Following the infamous murder of Kitty Genovese, in which numerous bystanders heard her cries but did not intervene, Darley and Latane conducted an experiment under similar circumstances that showed a correlation between group size and tendency to intervene. ${ }^{130}$ Waller described how the bystander effect contributes to genocide:

The concept of diffusion of responsibility also can be applied to the repression of conscience. In an organization committed to the sanctioning of inhumanity, no one person feels the pressure to say that such actions are wrong. There is a routinization of bureaucratic subroutines in which responsibility for evil is divided among members of the group. The larger the group, the less responsible any individual feels. This makes it possible for many perpetrators to claim a specious personal exception - "I personally did not kill anybody" - for their involvement in genocide and mass killing." 131

\footnotetext{
${ }^{128}$ Browning, 69.

${ }^{129}$ Waller, 251-252.

${ }^{130}$ Ibid., 248. Also see Darley and Latané, Bystander Intervention in Emergencies: Diffusion of Responsibility. Journal of Personality and Social Psychology, 8, (1968), 377-383, http://wadsworth.cengage.com/psychology_d/templates/student_resources/0155060678 _rathus/ps/ps19.html (accessed 18 January 2014).

${ }^{131}$ Ibid.
} 
The use of bureaucracy to facilitate diffusion of responsibility as described in Waller's quote is also noted by Staub. He argued that specialization and bureaucratization are methods of compartmentalization that allow the perpetrator to commit violent acts. Hannah Arendt recognized this tendency in Eichmann from his belief that the bureaucracy absolved him of responsibility for the crimes for which he was indicted: "With the killing of Jews I had nothing to do. I never killed a Jew, or a non-Jew, for that matter - I never killed any human being. I never gave an order to kill either a Jew or a non-Jew; I just did not do it.” ${ }^{\text {„32 }}$ Arendt also described the Nazi use of coded language to transmit messages throughout the bureaucracy without revealing the truth to those in the bureaucracy not deemed "bearers of secrets." ${ }^{133}$ Lastly, Browning described the use of division of labor that bureaucracy facilitated among the members of Reserve Battalion 101. Following the traumatic experience at Józefów, the Battalion revised their methods for their next large massacre at Łomazy. At Łomazy, the Battalion rapidly rotated shooters and avoided pairing shooters to victims, depersonalizing the process and reducing the resulting traumatic shock. ${ }^{134}$

The other mechanism that Waller argued increases the effect of group identification is that of rational self-interest, or the conscious decision to participate in evil acts based on calculated benefit by the perpetrator. He explained rational self-interest as manifesting as either professional self-interest, such as careerism, or personal self-interest. Staub has similarly noted this tendency in his concept of personal goal theory described in the previous section. Staub argued that personal goals related to the self can override moral goals through conflict resolution processes when certain conditions are present. ${ }^{135}$ Charles Tilly described violence that occurs due

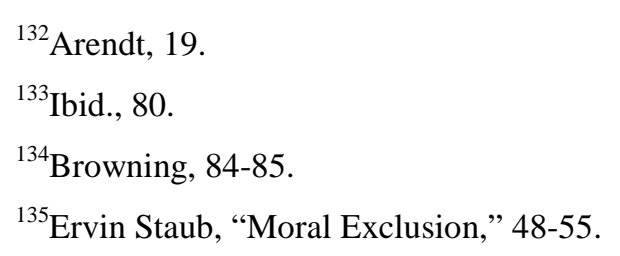


to self-interest of perpetrators as belonging to a category of violence he called "opportunism,” which, can result in "coordinated destruction,” or genocide, when the occurrence is widespread and well-coordinated in a society. He cited Rwanda as an example due to the prevalence of opportunistic acts such as "rape, plunder, revenge, and extortion.”" ${ }^{36}$ Arendt described the role that professional self-interest played in Eichmann's decision to enter the Nazi Schutzstaffel or SS. Upon cross-examination, Eichmann described himself as a passive participant in the decisions that brought him to the SS, blaming the poor economy and his lack of understanding of the Party.

Arendt disagreed, and asserted that self-interest was at play:

What Eichmann failed to tell the presiding judge in cross-examination was that he had been an ambitious young man who was fed up with his job as a traveling salesman even before the Vacuum Oil Company was fed up with him. From a humdrum life without significance and consequence the wind had blown him into History, as he understood it, namely, into a Movement that always kept moving and in which somebody like him - already a failure in the eyes of his social class, of his family, and hence in his own eyes as well - could start from scratch and still make a career. And if he did not like what he had to do, ... if he guessed, rather early, that the whole business would come to a bad end. . . he never forgot what the alternative would have been. ${ }^{137}$

\section{Binding Factors of the Group}

The final phenomenon that Waller stated contributes to the social construction of cruelty is what he called "binding factors of the group.” As the name implies, these are the psychological and sociological mechanisms that hold the group together and contribute to collective acts of evil. Waller listed three mechanisms that contribute to binding factors of the group, which include kin recognition cues, gender, and conformity to peer pressure. The first of these, kin recognition cues, is the tendency for people to show favoritism or commitment to those individuals more closely genetically related. Waller argued that military and paramilitary organizations manipulate these cues by requiring similarity among members, such as uniforms and mannerisms, and through use

\footnotetext{
${ }^{136}$ Tilly, 133-140.

${ }^{137}$ Arendt, 29-30.
} 
of language such as "homeland” or "brother-in-arms.", 138 The second mechanism contributing to binding factors of the group, gender, referred to the manipulation of gender to bind perpetrator groups. Waller noted the use of macho rituals to overcome the prohibitions against killing, as described previously, as an example. Lastly, conformity to peer pressure is the tendency to go along with the actions of a group. Waller argued that peer pressure is particularly powerful in military organizations due to the strong bonds that develop through training and military life what he calls "mutual surveillance," a bond so strong that a soldier would rather die than let his group down. ${ }^{139}$ Browning’s account of Reserve Police Battalion 101 exemplified this bond. Browning observed that despite initial disgust and reservation against killing, 80 to 90 percent of the men would go on to kill. He hypothesized that this was due to two reasons. The first was an aversion to being seen shirking their duty or passing on their "dirty work," by other members of the group so as not to risk "isolation, rejection, and ostracism” from the group. Second, objecting on moral grounds could be seen as a challenge to the esteem of others in the group, illustrated by the nonshooters' explanation that they were too "weak" or "cowardly" to shoot rather than too good or moral. ${ }^{140}$ Browning's account also indicated that conformity to peer pressure can have a powerful effect even when bonds between individuals have not yet formed. He noted that many men were new to the battalion at the time of the Józefów massacre, yet only a dozen out of nearly 500 excused themselves when the offer was presented by their leaders. In the words of one policeman present at the massacre, "[W]ho would have dared . . . to lose face before the assembled troops[?]"141

\footnotetext{
${ }^{138}$ Waller, 265.

${ }^{139}$ Ibid., 259.

${ }^{140}$ Browning, 187.

${ }^{141}$ Ibid., 71-72.
} 
In conclusion, this section has examined the mechanisms that encourage normal people to commit mass atrocities when placed in the particular set of circumstances that promote it. These mechanisms were grouped in accordance with Waller's social construction of cruelty into the categories of professional socialization, group identification, and binding factors of the group. Professional socialization includes escalating commitments, ritual conduct, and the merger of the role and person. Group identification consists of repression of conscience, which occurs through diffusion of responsibility and deindividuation, enabled by the bureaucracy, and rational selfinterest, which manifests as personal or professional self-interest. Lastly, binding factors of the group was concerned primarily with the role of peer pressure as a means of influencing potential perpetrators. Genocide prevention efforts aimed at perpetrators should counter these mechanisms, and the military capabilities that can accomplish this goal are addressed in later sections. The next section examines the causes and indicators related to the remaining element of the paradoxical trinity, the role of reason as it pertains to genocide leaders.

\section{Causes and Indicators: Leaders of Genocide}

The first section on the causes and indicators of genocide in this monograph focused on genocide from the bottom-up perspective that certain traits and mechanisms must be present in a society for genocidal acts to occur. The second section focused on how normal people can become perpetrators of mass violence. This final section examines genocide from the top-down perspective of the leaders of genocide, which are typically the government, and how they use genocide and mass killing as a tool to achieve their ends. Clausewitz argued that war is subordinated to reason by the government. ${ }^{142}$ This section examines how genocide, too, can be subordinated to reason and used to achieve the objectives of a genocidal leader. This section is divided into a discussion on authoritarianism, the type of government most prone to one-sided

\footnotetext{
${ }^{142}$ Clausewitz, 101.
} 
violence, and the work of political scientist Benjamin Valentino that examined genocide from a top-down, "strategic” perspective.

Authoritarianism

The most obvious characteristic of genocide leaders is that they are typically found in an authoritarian political system. As Rummel pointed out in his book, Death by Government, an unconscionable 128 million deaths can be attributed to the six most absolute states of the twentieth century - communist USSR, China, Cambodia, Vietnam, Yugoslavia, and Nazi Germany. ${ }^{143}$ This estimate of deaths gives weight to his statement that "Power kills; absolute Power kills absolutely.”144 This method of using violence to achieve political goals is easier in authoritarian and totalitarian political systems in which the leaders have unfettered access to the perpetrators of violence, and there are no political structures for opposition or minority views. This is not to say that democratic systems lack instances of one-sided violence. As sociologist Michael Mann noted, democracies carry the potential for the majority to tyrannize the minority, what he called the "dark side of democracy." ${ }^{145}$ However, the violence committed by authoritarian governments far outweighs that committed by more democratic systems.

\section{The Strategic Perspective}

While authoritarian governments have committed the majority of mass killing in the past century, Valentino argued that genocide cannot be sufficiently explained by the presence of an undemocratic government. Furthermore, he argued that the cultural and psychological mechanisms examined by contemporary genocide scholars, such as those covered in this monograph, are also insufficient to explain occurrences of genocide. Instead, Valentino insisted

\footnotetext{
${ }^{143}$ Rummel, 3.

${ }^{144}$ Ibid., 1.

${ }^{145}$ Michael Mann, The Dark Side of Democracy: Explaining Ethnic Cleansing (New York:
} Cambridge University Press, 2005), 4. 
that genocide research must begin with "the specific goals and strategies of high political and military leaders, not with broad social or political factors.” ${ }^{146}$ From this starting point, he argued that genocide can best be viewed from a "strategic perspective.” As he explained, "[t]he strategic perspective suggests that mass killing is most accurately viewed as an instrumental policy - a brutal strategy designed to accomplish leaders' most important ideological or political objectives and counter what they see as their most dangerous threats.” ${ }^{147}$ Viewing genocide from the strategic perspective, Valentino proposed a typology of mass killing based on the intent of the leaders that identified six specific motives for mass killing that corresponded to six types of mass killing. He then grouped these six types into two broad categories: dispossessive mass killing and coercive mass killing.

Table 2: Valentino’s Intent-Based Typology of Mass Killing.

\begin{tabular}{|c|c|c|}
\hline Motive/Type & Scenario & Selected Examples \\
\hline & \multicolumn{2}{|l|}{ DIPOSSESSIVE MASS KILLING } \\
\hline Communist & $\begin{array}{l}\text { Agricultural } \\
\text { collectivization and } \\
\text { political terror }\end{array}$ & $\begin{array}{l}\text { Soviet Union } \\
\text { China } \\
\text { Cambodia }\end{array}$ \\
\hline Ethnic & Ethnic Cleansing & $\begin{array}{l}\text { The Holocaust } \\
\text { Rwanda }\end{array}$ \\
\hline Territorial & $\begin{array}{l}\text { Colonial Enlargement } \\
\text { Expansionist Wars }\end{array}$ & $\begin{array}{l}\text { Genocide of the Herero in German Southwest } \\
\text { Africa } \\
\text { German annexation of western Poland }\end{array}$ \\
\hline & \multicolumn{2}{|l|}{ COERCIVE MASS KILLING } \\
\hline Counterguerilla & Guerilla Wars & $\begin{array}{l}\text { Algerian ware of independence from France } \\
(1945-62) \\
\text { Soviet invasion of Afghanistan } \\
\quad(1979-88)\end{array}$ \\
\hline Terrorist & $\begin{array}{l}\text { Terror bombing } \\
\text { Starvation blockages / siege } \\
\text { warfare } \\
\text { Sub-state / insurgent terrorism }\end{array}$ & $\begin{array}{l}\text { WWII Allied bombings of Germany and Japan } \\
\text { Nigerian land blockade of Biafra } \\
\text { Viet Cong terrorism in South Vietnam }\end{array}$ \\
\hline Imperialist & Imperial conquests and rebellions & Japan’s empire in East Asia \\
\hline
\end{tabular}

Source: Valentino, 71.

\footnotetext{
${ }^{146}$ Valentino, 2.

${ }^{147}$ Ibid., 3.
} 
The first of Valentino's categories of mass killing, dispossessive mass killings, are the result of policies that "strip large groups of people of their possessions, their homes, or their way of life.” ${ }^{148}$ He noted that mass killing is usually not the intended outcome of such policies, but often results from their implementation. Valentino further divided this category by intent into the subcategories of communist, ethnic, and territorial killings based on whether the intended outcome was a communist society, ethnic cleansing, or territorial expansion. Dispossessive mass killings and its subcategories include the deadliest episodes of genocide of the twentieth century. Valentino's second category of mass killing, coercive mass killing, is what he describes as "simply war by other means." ${ }^{149}$ He described such episodes of mass killing as resulting from conflicts in which a combatant cannot defeat another combatant through conventional military means. When such conflicts threaten the leaders' objectives, they sometimes attack their opponent's base of civilian support, which can escalate to large-scale genocide. Mass killing is not the goal of such attacks; however, the frustration from continued conflict leads to less selective targeting of opponent groups or even the surrounding noncombatant population. Valentino divided coercive mass killings into three subgroups: counterguerilla, terrorist, and imperialist. Counterguerilla refers to the targeting of civilian base through which guerilla opponents move, for which Valentino offered the analogy of "catch[ing] the fish by draining the sea.”150 The terrorist category includes mass killing of civilians in an attempt to quickly end a conflict, a grouping that includes both strategic bombing by legitimate governments and mass killing by substate actors. Lastly, the imperial category consists of mass killings of indigenous populations as a means for imperial powers to increase their control over a population.

\footnotetext{
${ }^{148}$ Valentino, 3.

${ }^{149}$ Ibid., 81.

${ }^{150}$ Ibid., 82.
} 
In addition to his typology of mass killing, Valentino’s strategic perspective has profound implications on the prediction and prevention of genocide and mass killing. First, he argued that prediction should be limited to those regimes "attempting to implement radical social changes that materially dispossess large numbers of people in a short period of time, those seeking the physical expulsion of large groups of people, or those trying to defeat mass-based guerilla insurgencies.” ${ }^{151}$ Second, since the strategic perspective sees genocide as a strategy implemented by political or military elites to achieve political goals, genocide prevention efforts should focus on disarming or removing those leaders from power. Valentino noted that deterrence actions such as sanctions and air strikes may have some utility for preventing mass killing; however, he recommended traditional military operations designed to “defeat the perpetrator's military forces, protect victim groups on the ground, and provide humanitarian assistance to refugee populations." 152

${ }^{151}$ Valentino noted that this statement only addressed the communist, ethnic, and counterguerilla subcategories of mass killing due to the limitations of his research and the relative rarety of instances of mass killing from the other subgroups. Valentino, 240.

${ }^{152}$ Ibid., 243. 


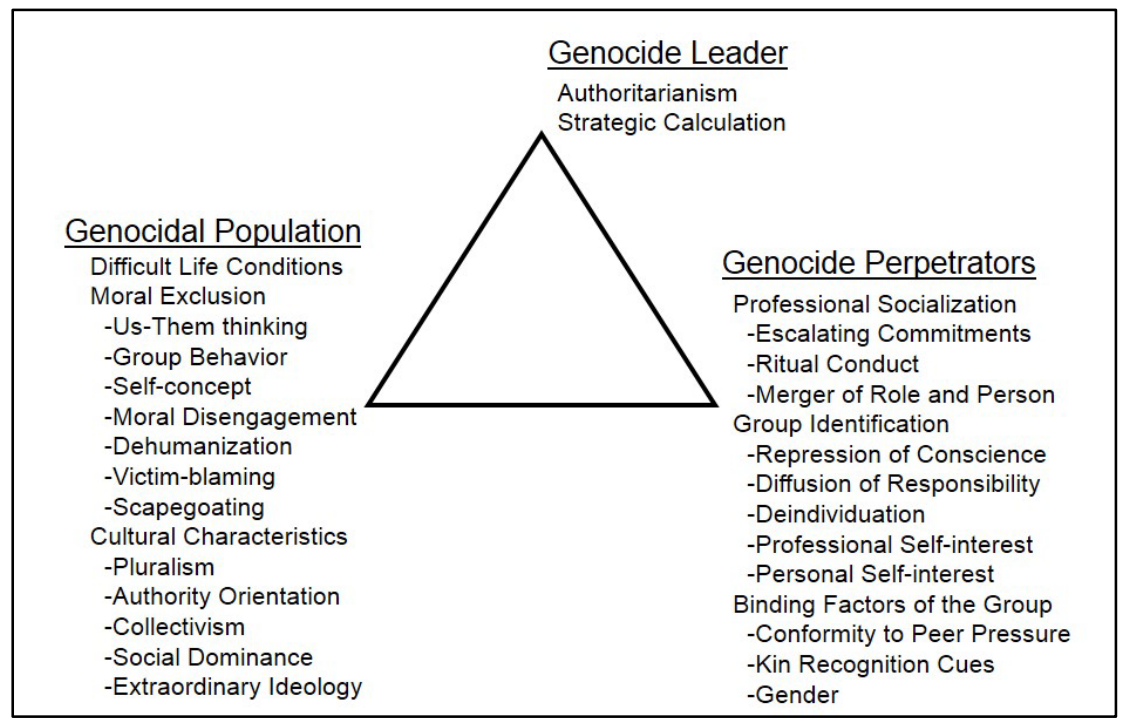

Figure 4: Causes and Indicators of Genocide Expressed Through the Trinity.

Source: Created by author.

\section{LEVERAGING THE TRINITY: GENOCIDE PREVENTION}

The previous sections examined the causes and indicators of genocide from the perspective that genocide is a form of war and therefore manifests through the phenomenon of the trinity that Clausewitz observed in the eighteenth century. This method of analysis revealed that genocide is the product of a confluence of psychological mechanisms and societal characteristics that mobilize the will of the people, psychological mechanisms that allow perpetrators to conduct acts of mass killing, and a strategic calculation made by genocide leaders to achieve their political objectives. Additionally, Harff's risk assessment model and Stanton's stages of genocide show that genocide can be predicted before mass atrocities occur, allowing time for the application of genocide prevention actions. This chapter applies this knowledge by matching the indicators and causes of genocide with military capabilities that can be used to counteract their influence. The resulting prevention framework is organized around the trinity and its categories of genocidal 
population, genocide perpetrators, and genocide leaders, which can be used as lines of effort in an operational approach to genocide prevention. ${ }^{153}$

\section{Genocide Prevention Efforts Targeting the Genocidal Population}

This section examines the military capabilities that can be used to counter the psychological mechanisms and societal characteristics that mobilize the will of the people and increase the propensity for genocide within a society. As covered in the previous chapter, these include difficult life conditions, psychological mechanisms that facilitate moral exclusion, and certain cultural characteristics. The overall theme for the capabilities presented in this section is development and information.

The first chapter of this monograph established that difficult life conditions are a common aspect of societies subjected to genocide. Military capabilities can alleviate some of the worst effects of such conditions. The joint force can meet basic needs such as food, water, shelter, clothing, and medical services through the provision of foreign humanitarian assistance. ${ }^{154}$ However, this may not be enough to stop mass killings from occurring. Staub’s personal goal theory, which was examined in the first section, stated that people can resort to violence when their personal goals are frustrated. ${ }^{155}$ Foreign humanitarian assistance may meet basic needs, but is unlikely to meet a majority of individual goals within a population; however, military forces can provide other types of support that may improve the population's ability to meet individual goals without resorting to violence. Through Humanitarian and Civic Assistance activities, the

\footnotetext{
${ }^{153}$ ADRP 5-0 defines lines of effort as linking "multiple tasks using the logic of purpose . . . to focus efforts toward establishing operational and strategic conditions." US Department of the Army, Army Doctrinal Reference Publication (ADRP) 5-0, The Operations Process (Washington DC: Headquarters, US Department of the Army, May 2012), http://armypubs.army.mil/doctrine/DR_pubs/dr_a/pdf /adrp5_0.pdf (accessed 5 March 2014).

${ }^{154}$ US Department of Defense, JP 3-29, Information Operations (Washington, DC: Government Printing Office, 2014), I-6.

${ }^{155}$ Staub, “Moral Exclusion,” 48-55.
} 
joint force can provide veterinary care in rural areas, construction of rudimentary surface transportation systems, well drilling, and construction of public facilities. ${ }^{156}$ Additionally, depending on the level of access to the affected nation, the joint force may be able to support larger agricultural and infrastructure projects aimed at increasing economic opportunities within the population.

The second set of phenomena concerning the affected population that were examined in the previous chapter were those of moral exclusion. Moral exclusion is the mechanism through which a group of people can exclude another group from moral consideration, and was divided into the related psychological mechanisms of us-them thinking, group behavior, self-concept, moral-disengagement, and victim-blaming. The use of information capabilities presents an opportunity to counter these psychological mechanisms. They can be counteracted through the use of military information support operations (MISO), which are military operations to influence the "emotions, motives, objective reasoning, and ultimately the behavior of foreign governments, organizations, groups, and individuals.” ${ }^{157}$ Such operations could be used to promote the narratives of unity and solidarity between groups to counter the psychological mechanisms that divide the affected population. Military information support operations can also be used to counteract the dehumanizing propaganda that facilitates moral disengagement and scapegoating. Additionally, information that mass killings are occurring can have a profound effect on the international community and members of the affected population. It has been shown that even the Nazis backed away when faced with public protests against their actions. ${ }^{158}$ A combination of

\footnotetext{
${ }^{156}$ US Department of Defense, JP 3-29, Information Operations, I-9.

${ }^{157}$ Ibid., JP 3-13, Foreign Humanitarian Assistance (Washington, DC: Government Printing
} Office, 2012), II-9-II-10.

${ }^{158}$ Staub, The Roots of Evil, 87. Staub referenced the protests in Bulgaria and the subsequent refusal to turn over the Jewish population and and in Germany when relatives protested the killing of family. 
public information and military information support operations could be used to rally international support and incite sympathetic views within the affected population.

The final concepts regarding the affected population that were examined in the previous chapter were cultural characteristics that contribute to the propensity for genocide within a society. These characteristics include the degree to which a society is pluralistic, and the society's orientation towards authority, social dominance, and collectivism. Information capabilities again provide a means to address these societal characteristics.

The first of the cultural characteristics examined was the degree to which a society is pluralistic, or the degree to which differences in opinions and beliefs are present in a society. When there is a lack of conflict resolution mechanisms for those differences and extreme inequality is present between groups, a society is more likely to experience mass violence. The solution to this problem is to foster the development of conflict resolution mechanisms such as those found in democratic forms of governance. The recommendation to develop democratic institutions as a means of genocide prevention is a common theme of genocide literature. ${ }^{159}$ As Rummel explained, “[t]he more constrained the power of governments, the more power is diffused, checked, and balanced, the less it will aggress on others and commit democide.” 160 Democratic institutions provide a means of diffusing, checking, and balancing the power of a state, and should form the basis of any program of genocide prevention. The joint force should support the Department of State's diplomatic efforts to bring about democratic reform in at-risk nations through the use of MISO and strategic communications.

\footnotetext{
${ }^{159}$ Linda Woolf and Michael Hulsizer, "Psychosocial roots of genocide: risk, prevention, and intervention," Journal Of Genocide Research 7, no. 1 (March 2005): 123, Academic Search Complete, EBSCOhost (accessed 31 March 2014). David A. Hamburg, Preventing Genocide: Practical Steps Toward Early Detection and Effective Action (Boulder, CO: Paradigm Publishers, 2008),117. Kuper, Genocide, 188-189.

${ }^{160}$ Democide refers to "the murder of any person or people by a government, including genocide, politicide, and mass murder.” Rummel, 2.
} 
The remaining cultural characteristics that mobilize the will of the people to support genocide as indicated by the research include authority orientation, social dominance, collectivism, and ideology. Authority orientation, social dominance, and collectivism are developed through socialization through the family starting as early as childhood and reinforced daily through social interactions. The use of information to counter these characteristics through the advancement of narratives stressing individualism and equality presents an opportunity, although the degree to which they would be successful is questionable due to the deeply held nature of such beliefs. Extraordinary ideology presents an easier target owing to the amount of effort required to instill and maintain such beliefs within a society. ${ }^{161}$ Military information capabilities should be used to counteract or inhibit the dissemination of propaganda that promotes potentially genocidal ideology or to replace it with a competing narrative.

This section has examined the military capabilities that can be used to counter the psychological mechanisms and societal characteristics that mobilize the will of the people and increase the propensity for genocide within a society. These include difficult life conditions, psychological mechanisms that facilitate moral exclusion, and certain cultural characteristics. US military forces possess unique information capabilities and development tools that can be used to counter these psychological mechanisms and societal characteristics in order to prevent genocide in its early phases. The remaining subsections examine the prevention capabilities that can be used to target potential perpetrators of genocide and change the strategic calculation of genocide leaders.

\footnotetext{
${ }^{161}$ Kiernan described the "pragmatic skill” necessary to implement mass killing. In his own words: "The huge endeavor of mass killing requires mobilization of enormous human, material, and administrative resources. ... It needs incitement, organization, guile, and denial, often simultaneously. The very variety of audiences requires a mixture of messages, often contradictory.” Kierman, Blood and Soil, 33-35.
} 


\section{Genocide Prevention Efforts Targeting Potential Perpetrators of Genocide}

This section examines the military capabilities that can be used to counter potential perpetrators of genocide. The research on genocide literature has shown that certain social mechanisms allow so-called normal people to commit mass atrocities when placed in the particular set of circumstances that promote it. These mechanisms were grouped in accordance with Waller's social construction of cruelty into the categories of professional socialization, group identification, and binding factors of the group. The category of professional socialization consists of escalating commitments, ritual conduct, and the merger of the role and person. Group identification consists of repression of conscience, which occurs through diffusion of responsibility and deindividuation, enabled by the bureaucracy, and rational self-interest that manifests as personal or professional self-interest. Lastly, binding factors of the group was concerned primarily with the role of peer pressure as a means of influencing potential perpetrators. The following section examines the military capabilities that can counter these mechanisms, and is organized under the general theme of military engagement, which includes partnership activities such as security cooperation and special warfare activities such as MISO. ${ }^{162}$

The primary difficulty of countering the mechanisms that contribute to perpetrator behavior is the amount of separation, both physically and temporally, between prevention actions and situations in which the potential perpetrator must make the decision on whether to participate in mass killing. Stated simply, genocide prevention prior to a MARO assumes that US forces will not be present to physically intervene when a perpetrator makes the decision to participate in a mass killing. Owing to this separation, prevention efforts must be indirect in nature through actions that influence the potential perpetrator's decision when faced with a mass killing

${ }^{162}$ US Army Training and Doctrine Command, TRADOC Pam 525-8-5, US Army Functional Concept for Engagement (Fort Monroe, Virginia: Headquarters, United States Army 2014), 12-15, http://www.tradoc.army.mil/tpubs/pams/tp525-8-5.pdf (accessed 5 March 2014). 
situation, or persuade the perpetrator organization to adopt practices that make mass killings less likely. The majority of these actions can be achieved through the DoD Security Cooperation (SC) program. SC includes the activities taken by the DoD that enable international partners to achieve the strategic objectives of the US Government (USG). The Defense Security Cooperation Agency’s Security Assistance Management Manual provides a detailed explanation of SC activities, which include:

[A]ll DoD interactions with foreign defense and security establishments, including all DoD-administered Security Assistance (SA) programs, that build defense and security relationships; promote specific US security interests, including all international armaments cooperation activities and SA activities; develop allied and friendly military capabilities for self-defense and multinational operations; and provide US forces with peacetime and contingency access to host nations. ${ }^{163}$

SC includes both Security Cooperation programs and Security Assistance programs, originating from different authorities, but with significant overlap of activities between both sets of programs. The programs relevant to the discussion of genocide prevention include the provision of training and education programs to foreign militaries, and other forms of capacity building that may be leveraged to bring about reforms in foreign militaries.

Military training and education programs provided by US military forces provide a venue through which to educate foreign militaries and certain cases of foreign law enforcement and civilians on ethics and instill respect for human rights. For example, the Western Hemisphere Institute for Security Cooperation (WHINSEC) practices this method of security cooperation for western hemisphere partner nations. WHINSEC provides courses on ethics, human rights, and democracy that can be taken in addition to its officer and noncommissioned officer professional

\footnotetext{
${ }^{163}$ Defense Security Cooperation Agency, “Security Assistance Management Manual,” Security Cooperation Overview and Relationships, http://www.samm.dsca.mil/chapter/chapter-1 (accessed 10 February 2014).
} 
development courses. ${ }^{164}$ Similar programs could be established for other Combatant Commands through the use of mobile training teams to train and educate other foreign military forces.

The use of training and education programs as a method of moral engagement represent a use of what international relations scholar Joseph Nye, Jr. calls soft power. Soft power is a form of acquiescence brought about by "attraction to shared values and the justness of duty of contributing to the achievement of those values.” ${ }^{165}$ By exercising soft power through moral engagement, US military forces can provide potential perpetrators with the knowledge to recognize and counter the mechanisms that contribute to perpetrator behavior. This will allow them to think beyond situational factors such as peer pressure, escalating commitments, and repression of conscience when they are faced with a potentially violent situation. Additionally, training that conveys the understanding that perpetrators of mass killings will be held accountable for their actions and that any personal gains will be temporary can counter the influence of rational self-interest. Furthermore, educating on aspects of accountability and the potential consequences for atrocity perpetrators can be used to convey an essence of threat greater than that of 'softer' moral engagement.

In addition to training and education, security reform within foreign militaries and the use of MISO provides additional means to counter the mechanisms that contribute to perpetrator behavior. The other programs that fall under SC, such as those that sustain or equip foreign military forces, can be used as leverage to bring about reforms within foreign governments and

\footnotetext{
${ }^{164}$ Western Hemisphere Institute for Security Cooperation, "The Profession of Arms at WHINSEC,” US Army Maneuver Center of Excellence, http://www.benning.army.mil/tenant/whinsec/hr.html (accessed 20 February 2013).

${ }^{165}$ Nye excluded the military as a source of soft power in his book, Soft Power, and instead listed the behaviors of coercion, deterrence, and protection as the outcome of military usage; however, in his later work, Smart Power, Nye noted that the broader range of military missions such as humanitarian assistance and security cooperation do represent sources of soft power. Joseph S. Nye, The Future of Power (New York: PublicAffairs, 2011), 6-7. Nye, Soft Power: The Means to Success in World Politics (New York: Public Affairs, 2004), 31.
} 
militaries that contribute to genocide prevention. For example, requiring human rights vetting for promotion and retention can be used to counteract the influence of professional self-interest. Similarly, establishing rules against certain types of ritual conduct could also be an outcome of military reform. MISO, on the other hand, can be used to degrade the cohesion of perpetrator groups to counteract the influence of peer pressure and ritual conduct.

In conclusion, this section examined the military capabilities that can be used to counter potential perpetrators of genocide. These capabilities rely on indirect influence to affect the potential perpetrator's decision when faced with a mass killing situation, or persuade the perpetrator organization to adopt practices that make mass killings less likely. These capabilities fall under a general theme of military engagement and include partnership activities such as security cooperation, particularly the use of training and education programs as a form of moral engagement, and special warfare activities such as MISO. The following section examines the prevention capabilities that can be used to change the strategic calculation of genocide leaders.

\section{Genocide Prevention Efforts Targeting Leaders of Genocide}

The previous section on genocide leaders examined genocide from the top-down perspective of the leaders of genocide, and how they use genocide and mass killing as a tool to achieve their ends. The research indicated that genocide leaders are likely to be found operating in authoritarian political systems, which also comprise the deadliest of regimes of the twentieth century. Genocide prevention actions should therefore include efforts utilizing all elements of national power to achieve democratic reform in at-risk nations. As noted in the section on the affected population, the joint force can support USG efforts through the use of MISO and strategic communications in order to influence the target population and key leaders or to transmit strategic messages to international partners. The section on genocide leaders also examined Valentino's concept of genocide from the strategic perspective, or as a strategy designed to achieve a leader's key ideological or political objectives. This section examines the military 
capabilities that can be used to counter this strategy, which fall under a general theme of deterrence.

Valentino's strategic perspective of genocide argued that prevention efforts should focus on disarming or removing the genocide leaders from power. While the efficacy of such methods of direct military intervention are proven, they are also oftentimes politically untenable, or require such a high threshold of violence that intervention occurs after conflict within a society has already reached genocidal levels. The use of deterrence provides an additional option that can counter the genocide leader's strategic use of genocide.

Deterrence is the threat of force in order to change an adversary's behavior. JP 3-0 describes deterrence as an adversary's "belief that a credible threat of retaliation exists, the contemplated action cannot succeed, or the costs outweigh the perceived benefits of acting.”166 JP 5-0 contains an appendix of Flexible Deterrent Options (FDO) for each of the elements of national power - diplomatic, informational, military, and economic. FDO are pre-planned deterrence actions that can be used to influence an adversary's actions. Military FDO include increasing readiness posture of forces; upgrading alert status; increasing intelligence, surveillance, and reconnaissance; initiating show-of-force operations, conducting training and exercises; increasing protective measures; deploying forces near a potential operational area; and increasing information operations (IO). ${ }^{167}$ FDO should be used to alter the strategic calculation of genocide leaders by conveying the understanding that their goals will not be achieved, and that they have more to lose than gain from initiating a strategy of mass killing.

FDO provide a powerful tool for genocide prevention because they carry the threat of hard military power. FDO have also proven to be effective in the past. Operation Golden

${ }^{166}$ US Department of Defense, JP 3-0, Joint Operations (Washington, DC: Government Printing Office, 2011), V-10. E-3.

${ }^{167}$ Ibid., JP 5-0, Joint Operation Planning (Washington, DC: Government Printing Office, 2011), 
Pheasant provides an example of the efficacy of FDO, in this case, a show-of-force operation.

Operation Golden Pheasant was conducted in 1988 to deter a cross-border raid by Nicaraguan

Sandinista forces into neighboring Honduras. Approximately 3,100 Soldiers from the 82nd

Airborne Division and 7th Infantry Division (Light) conducted a parachute insertion and air-land operation under the pretense of a training exercise. ${ }^{168}$ The show-of-force worked as planned, and the Sandinistas withdrew their forces back to Nicaragua. Operation Golden Pheasant illustrates how FDO such as a show-of-force operation could be used to challenge a leader's strategic objectives in order to achieve effective genocide prevention without resorting to combat operations.

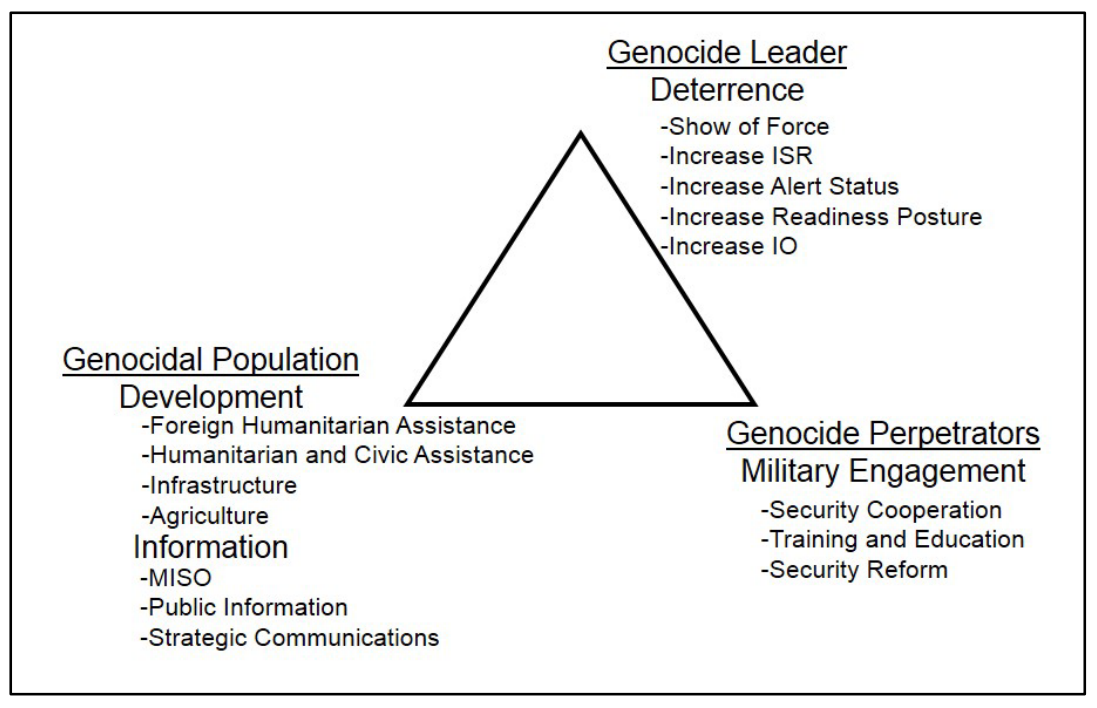

Figure 5: ‘Trinitarian’ Framework for Genocide Prevention.

Source: Created by author.

${ }^{168}$ Kevin Dougherty, The United States Military in Limited War; Case Studies in Success and Failure, 1945-1999 (Jefferson, NC: McFarland \& Company, 2012), 110-120. US Department of the Army, “82nd Airbirne Division History,” Fort Bragg, http://www.bragg.army.mil/82nd/Pages/History.aspx (accessed 5 March 2014). 


\section{CONCLUSION: RISK AND OPPORTUNITY FOR THE MILITARY IN GENOCIDE PREVENTION}

This monograph examined the causes and indicators of genocide from the Clausewitzian perspective that genocide, like war and other forms of collective violence, is "a continuation of political intercourse, carried on with other means.” Clausewitz described war as a paradoxical trinity composed of passion, chance, and reason, which are the concerns of the people, the army, and the government. As a Clausewitzian phenomenon, this monograph extended the trinity to genocide and its corresponding roles of the genocidal population, genocide perpetrators, and genocide leaders, in order to achieve a greater understanding of its causes. The research revealed that the factors concerning the genocidal population include the presence of difficult life conditions, the psychological mechanisms that contribute to moral exclusion of others, and certain cultural characteristics found in genocidal societies. Those concerning the genocide perpetrators include a list of mechanisms grouped into the categories of professional socialization, group identification, and binding factors of the group. Lastly, the "strategic perspective” of whether to implement a strategy of annihilation is the concern of genocide leaders. The monograph then matched these factors with the military capabilities that are best suited to counter them, which fall under the general themes of information and development, military engagement, and deterrence, respectively. The result is a framework for genocide and mass atrocity prevention that planners can use to guide actions in Phases 0 and 1 , the period when genocide indicators are present but large-scale violence has not commenced, with the goal of obviating the need for full-scale mass atrocity response operations.

As with all military operations, there is risk associated with this framework for genocide and mass atrocity prevention. As previously stated, genocide is a complex and fragile phenomenon that has a tendency to quickly escalate or morph into other kinds of violence. Any method of prevention may result in a change in the tempo or type of violence. The prevention 
capabilities recommended are also indirect in nature and may result in unforeseen complications. Contingencies should be prepared in the event that genocide escalates or other challenges arise.

This framework also presents a number of opportunities for military forces tasked with preventing genocide. The first of these is concerned with the Regionally Aligned Forces (RAF) that the US Army is already implementing. RAF provide combatant commanders with "versatile, responsive, and consistently available Army forces” to support operational missions, exercises, and security cooperation. ${ }^{169}$ A RAF that is properly sourced and trained could apply the prevention methods described in this monograph while being prepared to conduct a full-scale MARO if the need arises. This use of the RAF for genocide prevention would link prevention efforts and response efforts, allowing for a seamless transition through all phases of a genocide prevention and response operation.

The second opportunity concerns the US Army's emphasis on engagement with foreign nations. In order to recognize the Army’s continuing missions to "advise and assist foreign security forces, governments, and peoples,” the Army established engagement as a separate warfighting function. The engagement warfighting function is concerned with the human aspects of conflict and the "tasks and systems that influence the behaviors of a people, security forces, and governments.” ${ }^{170}$ The majority of the genocide prevention capabilities recommended in this monograph fall under the engagement warfighting function. The US Army should examine how engagement capabilities can support genocide prevention in order to "prevent, shape, and win” before conditions on the ground demand a full-scale MARO. ${ }^{171}$

\footnotetext{
${ }^{169}$ US Department of the Army, "Regionally Aligned Forces,” US Army Stand-To, http://www.army.mil/standto/archive/issue.php?issue=2012-12-20 (accessed 14 March 2014).

${ }^{170}$ US Army Training and Doctrine Command, TRADOC Pam 525-8-5, US Army Functional Concept for Engagement (Fort Monroe, Virginia: Headquarters, United States Army, 2014), http://www.tradoc.army.mil/tpubs/pams/tp525-8-5.pdf (accessed 5 March 2014).

${ }^{171}$ The Army will focus strategic priorities on three roles: prevent conflict, shape the operational environment, and win the Nation's wars. Ibid., TRADOC Pam 525-3-0, The United States Army Capstone
} 
Lastly, there are many opportunities for additional research on genocide prevention and response. The bulk of the literature on genocide and mass atrocities originated in the disciplines of history, sociology, political science, and psychology. This monograph examined genocide from a different perspective, that of a military practitioner, and attempted to synthesize the research of other disciplines through the lens that genocide is a form of war. There is a wealth of research on the phenomenon of war that will likely yield additional insights if applied to genocide as a form of war. Additionally, there is little research on the effectiveness of the military capabilities recommended in this monograph, particularly those associated with the new engagement warfighting function. Research that reveals the effectiveness of these methods would facilitate an informed response to genocide and other forms of conflict.

Genocide was one of the defining problems of the last century; it need not be a problem in this century. This monograph has shown that genocide can be viewed as a form of war resulting from contentious politics that follows the logic of Clausewitz's paradoxical trinity. It synthesized the existing literature on indicators and causes of genocide and showed that the US military possesses a number of tools that can be used to prevent genocide and mass atrocities before they result in large-scale death and destruction. The framework advanced in this monograph along with existing MARO doctrine gives the USG a set of tools that can be used to prevent and respond to genocide and mass atrocities in the hope that this century can uphold last century’s promise of “never again.”

Concept (Fort Eustis, Virginia: Headquarters, United States Army, 2012), http://www.tradoc.army.mil/tpubs/pams/tp525-3-0.pdf (accessed 24 August 2013). 


\section{BIBLIOGRAPHY}

Adorno, Theodor W. The Authoritarian Personality. New York: Harper, 1950.

http://www.ajcarchives.org/main.php?GroupingId=6490 (accessed 23 January 2014).

Appian. Appian's Roman History in Four Volumes. [Tome]1. Edited and translated by Horace White. London; Cambridge: W. Heinemann; Harvard University Press, 1972. http://penelope.uchicago.edu/Thayer/E/Roman/Texts/Appian/home.html (accessed 29 March 2014).

Arendt, Hannah. Eichmann in Jerusalem; A Report on the Banality of Evil. New York: Viking Press, 1963.

Baum, Steven K. The Psychology of Genocide: Perpetrators, Bystanders, and Rescuers. Cambridge: Cambridge University Press, 2008.

Browning, Christopher R. Ordinary Men: Reserve Police Battalion 101 and the Final Solution in Poland. New York: HarperCollins, 2001.

Chalk, Frank Robert, and Kurt Jonassohn. The History and Sociology of Genocide: Analyses and Case Studies. New Haven: Yale University Press, 1990.

Clausewitz, Carl von. On War. Edited by Michael Howard and Peter Paret. New York: Knopf, 1993.

Defense Security Cooperation Agency. “Security Assistance Management Manual.” Security Cooperation Overview and Relationships. http://www.samm.dsca.mil/chapter/chapter-1 (accessed 10 February 2014).

Dicks, Henry. "Dicks on Germany Personality 2.” The Pursuit of the Nazi Mind. http://www.bbk.ac.uk/thepursuitofthenazimind/HD.php (accessed 21 January 2014).

Dougherty, Kevin. The United States Military in Limited War; Case Studies in Success and Failure, 1945-1999. Jefferson, NC: McFarland and Company, 2012.

Fein, Helen. Accounting for Genocide: National Responses and Jewish Victimization During the Holocaust. New York: Free Press, 1979.

_. "Genocide: A Sociological Perspective.” In Genocide: An Anthropological Reader, edited by Alexander Laban Hinton, 74-90. Oxford, UK: Blackwell, 2002.

Freedman, Lawrence. Deterrence. Cambridge, UK; Malden, MA: Polity Press, 2004.

Freud, Sigmund. Group Psychology and the Analysis of the Ego. Translated by James Strachey. Vienna, Austria: The International Psycho-Analytical Press, 1922. http://www.gutenberg.org/files/35877/35877-h/35877-h.htm\#page_001 (accessed 16 December 2013) Gutenberg Project.

Genocide Prevention Task Force, Madeleine Korbel Albright, William S. Cohen, and John C. Danforth. Preventing Genocide: A Blueprint for US Policymakers. Washington, DC: 
American Academy of Diplomacy, 2008.

http://www.ushmm.org/conscience/taskforce/pdf/report.pdf (accessed 16 December 2013).

Goldhagen, Daniel Jonah. Worse Than War: Genocide, Eliminationism, and the Ongoing Assault on Humanity. New York: PublicAffairs, 2009.

- Hitler's Willing Executioners: Ordinary Germans and the Holocaust. New York: Knopf, 1996.

Hamburg, David A. Preventing Genocide: Practical Steps Toward Early Detection and Effective Action. Boulder, CO: Paradigm Publishers, 2008.

Harff, Barbara and Gurr, Robert Ted. "Systematic Early Warning of Humanitarian Emergencies.” Journal of Peace Research 35, no. 5 (September 1988): 551-579.

http://www.jstor.org/discover/10.2307/425699?uid=3739744\&uid=2129\&uid=2134\&uid $=2 \& u i d=70 \& u i d=4 \& u i d=3739256 \&$ sid=21103887135883 (accessed 2 January 2014).

Hinton, Alexander Laban. Genocide: An Anthropological Reader. Oxford, UK: Blackwell, 2002.

International Commission on Intervention and State Sovereignty. The Responsibility to Protect. Ottawa: International Development Research Centre, 2001.

Jensen, Olaf, and Claus-Christian W. Szejnmann. Ordinary People as Mass Murderers: Perpetrators in Comparative Perspectives. Houndmills, Balsingstoke, Hampshire, UK: Palgrave Macmillan, 2008.

Kiernan, Ben. Blood and Soil: a World History of Genocide and Extermination from Sparta to Darfur. New Haven: Yale University Press, 2007.

Kuper, Leo. Genocide: Its Political Use in the Twentieth Century. New Haven: Yale University Press, 1982.

- The Prevention of Genocide. New Haven: Yale University Press, 1985.

Kuperman, Alan. "Mass Atrocity Response Operations: Doctrine in Search of a Strategy." Genocide Studies and Prevention 6, no. 1 (April 2011): 59-65.

Le Bon, Gustave. The Crowd: A Study of the Popular Mind. Kitchener: Batoche Books, 2001. http://socserv.mcmaster.ca/econ/ugcm/3ll3/lebon/Crowds.pdf (accessed 20 December 2013).

Lemkin, Raphael. Axis Rule in Occupied Europe. Clark, NJ: The Lawbook Exchange, 2005. http://books.google.com/books?id=y0in2wOY-W0C\&printsec=frontcover\&source=gbs_ ge_summary_r\&cad $=0 \# v=$ onepage \&q\&f=false (accessed 15 December 2013).

Mann, Michael. The Dark Side of Democracy: Explaining Ethnic Cleansing. New York: Cambridge University Press, 2005.

Milgram, Stanley. “Behavioral Study of Obedience.” Journal of Abnormal Psychology, 67, (1963): 371-78. Bobbs-Merrill Reprint Series in the Social Sciences. 
http://www.columbia.edu/cu/psychology/terrace/w1001/readings/milgram.pdf (accessed 12 December 2013).

Mill, John Stuart. Inaugural Address Delivered to the University of St. Andrews, 1 February 1867. London: Longmans, Green, Reader, and Dyer, 1867.

http://books.google.com/books?id=SokBAAAAQAAJ\&printsec=frontcover\&source=gbs _ge_summary_r\&cad=0\#v=onepage\&q\&f=false (accessed 18 November 2013).

Nye, Joseph S. The Future of Power. New York: PublicAffairs, 2011.

Soft Power: The Means to Success in World Politics. New York: Public Affairs, 2004.

Plutarch. Plutarch's Moralia. 2. Edited and translated by Frank Cole Babbitt. London:

Heinemann, 1992. http://penelope.uchicago.edu/Thayer/E/Roman/Texts/Plutarch/Lives /home.html (accessed 29 March 2014).

Polybius. The Histories. Vol. 6. Edited and translated by Paton, William Roger. Cambridge, MA: Harvard Univ. Press, 2000. http://penelope.uchicago.edu/Thayer/E/Roman/Texts/ Polybius/home.html (accessed 29 March 2014).

Power, Samantha. A Problem from Hell: America and the Age of Genocide. New York: Harper Perennial, 2007.

Pratto, Felicia, James Sidanius, Lisa M. Stallworth, and Bertram F. Malle. "Social dominance orientation: A personality variable predicting social and political attitudes.” Journal of Personality and Social Psychology 67, no. 4, 1994: 741-763.

Raymond, Dwight, Cliff Bernath, Don Braum, and Ken Zurcher. Mass Atrocity Prevention \& Response Options: A Policy Planning Handbook. Carlisle, PA: US Army Peacekeeping and Stability Operations Institute, 2012.

Rummel, R. J. Death by Government. New Brunswick, NJ: Transactions Publishers, 1994.

Sewell, Sarah, Dwight Raymond, and Sally Chin. Mass Atrocity Response Operations: A Military Planning Handbook. Cambridge: Harvard University Press, 2010.

Seybolt, Taylor B, and Stockholm International Peace Research Institute. Humanitarian Military Intervention: The Conditions for Success and Failure. Oxford, England; New York: Oxford University Press, 2007.

Shaw, Martin. The General Hybridity of War and Genocide. Journal of Genocide Research 9, no. 3 (September 2007): 461-473. http://puj-portal.javeriana.edu.co/portal/page/portal/ Facultad\%20de\%20Ciencias\%20Politicas\%20y\%20Relaciones\%20Internacionales/1docu mentos/The\%20general\%20hibridity\%20of\%20war\%20and\%20genocide\%5B1\%5D_0.p df (accessed 15 January 2014).

- War and Genocide: Organized Killing in Modern Society. Cambridge: Polity Press in association with Blackwell, 2003.

What Is Genocide? Cambridge: Polity, 2007. 
Stanton, Gregory H. “The Ten Stages of Genocide.” Genocide Watch. http://genocidewatch.org/genocide/tenstagesofgenocide.html (accessed 14 November 2013).

Staub, Ervin. "Moral Exclusion, Personal Goal Theory, and Extreme Destructiveness.” Journal Of Social Issues 46, no. 1 (Spring1990): 47-64. SocINDEX with Full Text, EBSCOhost (accessed 7 February 2014).

- The Roots of Evil: The Origins of Genocide and Other Group Violence. Cambridge, UK: Cambridge University Press, 1989.

Theriault, Henry. “The MARO Handbook: New Possibilities or the Same Old Militarism?” Genocide Studies and Prevention 6, no. 1 (April 2011): 7-31.

Thucydides, and Richard Crawley. The History of the Peloponnesian War. Digireads.com, 2009.

Tilly, Charles. The Politics of Collective Violence. Cambridge: Cambridge University Press, 2003.

Uğur Ümit Ügör. “Team America: Genocide Prevention?” Genocide Studies and Prevention 6, no. 1 (April 2011): 32-38.

United Nations. General Assembly Resolution 260A(III) of 9 December 1948. http://www.un.org/ga/search/view_doc.asp?symbol=a/res/260\%28III\%29 (accessed 1 January 2014).

- 2005 World Summit Outcome Document Fact Sheet. September, 2005. http://www.un.org/summit2005/presskit/fact_sheet.pdf (accessed 22 August 2013).

US Army Training and Doctrine Command. TRADOC Pam 525-3-0. The United States Army Capstone Concept. Fort Eustis, VA: Headquarters, United States Army, 19 December, 2012. http://www.tradoc.army.mil/tpubs/pams/tp525-3-0.pdf (accessed 24 August 2013).

. TRADOC Pam 525-3-1. The United States Army Operating Concept 2016-2028. Fort Monroe, VA: Headquarters, United States Army, 19 August, 2010.

http://www.tradoc.army.mil/tpubs/pams/tp525-3-1.pdf (accessed 24 August 2013).

. TRADOC Pam 525-8-5. US Army Functional Concept for Engagement. Fort Monroe, VA: Headquarters, United States Army, 24 February, 2014.

http://www.tradoc.army.mil/tpubs/pams/tp525-8-5.pdf (accessed 5 March 2014).

US Department of the Army. Army Doctrinal Reference Publication (ADRP) 5-0. The Operations Process. Washington, DC: Headquarters, US Department of the Army, May 2012. http://armypubs.army.mil/doctrine/DR_pubs/dr_a/pdf/adrp5_0.pdf (accessed 5 March 2014).

. "82nd Airbirne Division History.” Fort Bragg. http://www.bragg.army.mil/82nd/ Pages/History.aspx (accessed 5 March 2014).

_. "Regionally Aligned Forces.” US Army Stand-To. http://www.army.mil/standto/archive /issue.php?issue=2012-12-20 (accessed 14 March 2014). 
US Department of Defense. Sustaining US Global Leadership: Priorities for 21st Century Defense. January 2012. http://www.defense.gov/news/defense_strategic_guidance.pdf (accessed 24 August 2013).

—. JP 3-0. Joint Operations. Washington, DC: Government Printing Office, 11 August 2011.

- JP 3-07. Stability Operations. Washington, DC: Government Printing Office, 8 September 2011.

—. JP 3-07.3 Peace Operations. Washington, DC: Government Printing Office, 17 October 2007.

- JP 3-13. Foreign Humanitarian Assistance. Washington, DC: Government Printing Office, 27 November 2012.

—. JP 3-29. Information Operations. Washington, DC: Government Printing Office, 3 January 2014.

- JP 5-0. Joint Operation Planning. Washington, DC: Government Printing Office, 11 August 2011.

Valentino, Benjamin A. Final Solutions: Mass Killing and Genocide in the 20th Century. London: Cornell University Press, 2005.

Waller, James. Becoming Evil: How Ordinary People Commit Genocide and Mass Killing. Oxford; New York: Oxford University Press, 2007.

Weiss, Thomas George, and Ramesh Chandra Thakur. Global Governance and the UN an Unfinished Journey. Bloomington: Indiana University Press, 2010.

Weitz, Eric D. “The Modernity of Genocides: War, Race, and Revolution in the Twentieth Century.” In The Specter of Genocide Mass Murder in Historical Perspective. Edited by Robert Gellately and Ben Kiernan, 53-74. Cambridge: Cambridge University Press, 2003.

Welzer, Harald. "On Killing and Morality: How Normal People Become Mass Murderers. In Ordinary People as Mass Murderers, Perpetrators in Comparative Perspectives.” Edited by Olaf Jensen and Claus-Christian W. Szejnmann, 165-181. Houndmills, Balsingstoke, Hampshire, UK: Palgrave Macmillan, 2008.

Western Hemisphere Institute for Security Cooperation. "The Profession of Arms at WHINSEC." US Army Maneuver Center of Excellence. http://www.benning.army.mil/tenant/whinsec/ hr.html (accessed 20 February 2014).

The White House. National Security Strategy. 1 May 2010. http://www.whitehouse.gov/sites/ default/files/rss_viewer/national_security_strategy.pdf (accessed 24 August 2013).

Presidential Study Directive-10. Presidential Study Directive on Mass Atrocities. 4 August 2010. http://www.whitehouse.gov/the-press-office/2011/08/04/presidential-studydirective-mass-atrocities (accessed 24 August 2013). 
Woolf, Linda, and Michael Hulsizer. "Psychosocial roots of genocide: risk, prevention, and intervention." Journal Of Genocide Research 7, no. 1 (March 2005): 101-128. Academic Search Complete, EBSCOhost (accessed 31 March 2014).

Zimbardo, Philip, Craig Haney, and Curtis Banks. “Interpersonal Dynamics in a Simulated Prison.” International Journal of Criminology and Penology 1 (1973): 69-97. 